STUDIA HISTORICA GEDANENSIA

TOM IX (2018)

\title{
Michał Michalak
}

(Wydział Historyczny, Uniwersytet Gdański)

\section{Uzbrojenie w obrazach Jana van Eycka. Analiza bronioznawcza. Realizm czy symbolizm?}

Na wstępie niniejszego tekstu pragnę podziękować za cenne wskazówki: Panu prof. dr. hab. Witoldowi Świętosławskiemu oraz Panu dr. Jackowi Friedrichowi, a także Panu dr. Lechowi Markowi. Szczególne podziękowania za pomoc w nadaniu temu tekstowi właściwego kształtu i za wszelkie porady bibliograficzne chciałbym złożyć Panu prof. dr. hab. Antoniemu Ziembie.

Celem artykułu jest prezentacja wyników analizy bronioznawczej przeprowadzonej na czterech obrazach Jana van Eycka, na których zostały przedstawione przez artystę liczne militaria. Jako główny wątek wybrałem uzbrojenie ochronne noszone przez postacie archanioła Michała i św. Jerzego, części którego łączą ze sobą wszystkie omówione dzieła. Istotnym celem było również skatalogowanie i analiza porównawcza wszystkich namalowanych militariów. Temat został zrealizowany w dwóch częściach: w pierwszej zbadano, poprzez zestawienie $\mathrm{z}$ innymi wizerunkami ikonograficznymi z tego okresu, uzbrojenie namalowane przez van Eycka; druga - ma na celu skonfrontowanie namalowanych militariów ze średniowiecznym uzbrojeniem z kolekcji muzealnych.

W latach 1426-1430 van Eyck odbył kilka podróży dyplomatycznych na zlecenie księcia Burgundii Filipa III Dobrego ${ }^{1}$. Wśród krajów odwiedzonych przez artystę, oprócz Hiszpanii i Portugalii, znalazła się być może Italia ${ }^{2}$. Wcześniej, w latach 1422-25, van Eyck pracował na dworze hrabiów Holandii w Hadze, by w 1425 r. przejść na służbę księcia Burgundii, Filipa, w charakterze nadwornego malarza i dworzanina ${ }^{3}$. Potwierdzony źródłowo jest jego pobyt na dworze w Lille oraz w Brugii, a także praca w Gandawie, gdzie dla tamtejszego patrycjusza Jodokusa van Vijda wykonywał Poliptyk Gandawski (ukończony w 1432 r.). Od 1432 r. funkcjonowała

1 Antoni Ziemba, Sztuka Burgundii i Niderlandów, t. 2, Niderlandzkie malarstwo tablicowe 1430-1500 (Warszawa: Wydawnictwo UW, 2011), 218.

2 Ibidem, 482.

3 Jolanta Maurin-Białostocka, Jan van Eyck (Warszawa: RSW Prasa-Książka-Ruch, 1973), 6-7. 
pracownia mistrza Jana w Brugii ${ }^{4}$. Warsztat van Eycka działał nadal po śmierci malarza w 1441 r. i mógł być czynny jeszcze około 1450 r. ${ }^{5}$

W okresie panowania księcia Filipa III Dobrego w Burgundii (1419-1467) centrum zarządzania krajem przeniosło się z Dijon do Niderlandów ${ }^{6}$. Ulubioną rezydencją księcia Filipa stała się Brugia ${ }^{7}$. Kultura dworu burgundzkiego była przesycona rycerskimi ideałami kultywowanymi z całym splendorem ${ }^{8}$. W 1430 r. książę proklamował utworzenie rycerskiego zakonu Złotego Runa, którego członkowie zbierali się na posiedzeniach kapituły w trzech wymienionych siedzibach dworu burgundzkiego, w tamtejszych kościołach miejskich ${ }^{9}$. Brugia w okresie późnego średniowiecza stanowiła ważny węzeł handlowy pomiędzy Anglią, Hanzą i Półwyspem Iberyjskim ${ }^{10}$. W XIV w. istniało na terenie miasta pięć zorganizowanych kolonii kupieckich z Włoch, były to przedstawicielstwa Mediolanu, Lukki, Florencji, Genui i Wenecji ${ }^{11}$. Brugia wraz z innymi miastami niderlandzkimi, jak Gandawa, Tournai i Antwerpia, były ważnymi ośrodkami płatnerskimi ${ }^{12}$.

Dawniej przyjmowano, że pierwszymi chronologicznie dziełami van Eycka był zespół miniatur w Godzinkach Turyńsko-Mediolańskich (tzw. Ręka G), które tradycyjnie datowano na lata 1422-25, a niekiedy nawet na okres wcześniejszy. Współcześni badacze (Eberhard König, Thomas Krens, Till-Holger Borchert) przesuwają datowanie na późny okres twórczości van Eycka, na lata 1435-1440. Autorstwo miniatur budziło i nadal budzi pewne kontrowersje, niemniej większość uczonych utożsamia Rękę G z samym van Eyckiem, a przynajmniej uznaje ten

$4 \quad$ Ibidem, 6.

5 Ziemba, Sztuka Burgundii, t. 2, 521.

6 Ziemba, Sztuka Burgundii i Niderlandów 1380-1500, t. 1, Sztuka dworu burgundzkiego oraz miast niderlandzkich (Warszawa: Wydawnictwo UW, 2008), 23.

7 James M. Murray, Brugia kolebką kapitalizmu 1280-1390 (Warszawa: Wydawnictwo Naukowe PWN, 2011), 390.

8 Ziemba, Sztuka Burgundii, t. 1, 25-35. Zob. też: Die Kunst der burgundischen Niederlande. Eine Einführung, red. Birgit Franke, Barbara Welzel (Berlin: Dietrich Reimer Verlag, 1997); Wim P. Blockmans, Walter Prevenier, The Promised Lands: The Low Countries under Burgundian Rule, 1369-1530 (Pennsylvania: University of Pennsylvania Press, 1999). Bogaty materiał (w tym z zakresu bronioznawstwa) z okresu panowania następnego księcia burgundzkiego, Karola Śmiałego, daje katalog wystawy: Charles the Bold (1433-1477): Splendour of Burgundy, red. i oprac. Suzan Marti, Till-Holger Borchert, Gabriele Keck (Belgium: Mercatorfonds, 2009), wyd. niemieckie: Karl der Kühne (1433-1477). Kunst, Krieg und Hofkultur (Stuttgart: Belser, 2008).

9 Ziemba, Sztuka Burgundii, t. 1, 45. Zob. też: L’ordre de la Toison d'or, de Philippe le Bon à Philippe le Beau (1430-1505). Idéal ou reflet d'une société?, red. Pierre Cockshaw, Ch. Van den Bergen-Pantens, kat. wyst., Bibliothèque Royale de Belgique, Brussel (Turnhout 1960).

$10 \quad$ Murray, Brugia, 232; o kupcach włoskich 237.

$11 \quad$ Ibidem, 237.

12 Zdzisław Żygulski, Broń $w$ dawnej Polsce na tle uzbrojenia Europy i Bliskiego Wschodu (Warszawa: Wydawnictwo Naukowe PWN, 1975), 105. 
zespół za pracę warsztatową wykonaną z jego udziałem ${ }^{13}$. W związku z badaną tematyką militariów interesujące są dwie miniatury: Modlitwa na plaży oraz Pojmanie Chrystusa, obecnie uznawane za wytwór warsztatu van Eycka, z bezpośrednim udziałem mistrza ${ }^{14}$. Obie miniatury spłonęły w pożarze w $1904 \mathrm{r}$. i znamy je jedynie z zachowanych faksymiliów.

Kolejne dzieło, które zostało poddane analizie - to kontrowersyjny odnośnie do autorstwa dyptyk - Ukrzyżowanie i Sąd Ostateczny. Malowidło powstałe zdaniem niektórych badaczy $\mathrm{w}$ trakcie pobytu malarza $\mathrm{w}$ Portugalii, czyli około 1428 r., znajduje się obecnie w Metropolitan Museum of Art w Nowym Jorku ${ }^{15}$. Jednak inną możliwość podaje Till-Holger Borchert, którego zdaniem dyptyk powstał $\mathrm{w}$ warsztacie van Eycka w okresie późniejszym, nawet około 1440 r. - i dlatego obraz został omówiony na końcu niniejszego tekstu. Następne analizowane bronioznawczo obrazy to powstała w $1436 \mathrm{r}$. Madonna kanonika Jorisa van der Paele, z Groeningemuseum w Brugii, oraz datowany na $1437 \mathrm{r}$. mały tryptyk z Maria $z$ Dzieciątkiem tronująca $w$ kościele (na tablicy środkowej) i Św. Michałem Archaniołem $z$ fundatorem oraz Św. Katarzyna Aleksandryjskg (na skrzydłach) - ze Staatliche Kunstsammlungen, Gemäldegalerie Alte Meister w Dreźnie (tzw. Tryptyk Drezdeński) ${ }^{16}$.

W analizie uzbrojenia zostały wykorzystane różnego rodzaju porównawcze wizerunki ikonograficzne i artefakty, często z terenów odległych od miejsca powstania badanych dzieł van Eycka. Wynika to z założeń artykułu, czyli próby potwierdzenia realizmu namalowanych przez van Eycka militariów. Szukanie analogii w szerokim geograficznie zasięgu, w zasadzie na terenie całej łacińskiej Europy i nie tylko (chodzi tu o kraje o zachodnim modelu feudalizmu, ale również o tereny pogranicza kulturowego - jak państwa bałkańskie czy Wielkie Księstwo Litewskie), jest wynikiem faktu często powszechnego występowania tych samych odmian broni siecznej, drzewcowej, miotającej, a także uzbrojenia ochronnego w okresie późnego średniowiecza. Na terenie Europy, w drugiej połowie XIV w. i trwając do lat dwudziestych-trzydziestych XV stulecia, uwydatniło się zjawisko w uzbrojeniu ochronnym określane jako międzynarodowy styl płatnerski. Po tym okresie zaczęły już być widoczne wyraźne różnice pomiędzy zbrojami produkowanymi

13 Adam S. Labuda, „Jan van Eyck. Realista i narrator. Wokół struktury i źródeł artystycznych Ukrzyżowania nowojorskiego", Artium Qauestiones 5 (1991), plik do pobrania: strona internetowa https://repozytorium.amu.edu.pl/handle/10593/9591, dostęp: 29 VI 2018.

14 Ziemba, Sztuka Burgundii, t. 2, 513-521, il. 686 oraz 688.

15 Ibidem, 186, przyp. 261 i 221. Por. T.H. Borchert, Zur Einführung: Jan van Eyck und seine Werkstatt, w idem et al., Jan van Eyck und seine Zeit. Flämische Meister und der Süden. 1430-1530, kat. wyst., Groeningemuseum Brugge, Stuttgart 2002 (po niderl.: De eeuw van Van Eyck. De Vlaamse Primitieven en het Zuiden, 1430-1530 (Gent-Amsterdam: Ludion, 2002), oraz po ang.: The Age of Van Eyck: The Mediterranean World and Early Netherlandish Painting, 1430-1530 (London: Thames \& Hudson, 2002), 20; idem, Jan van Eyck (Hong Kong-Köln-London: Taschen, 2008), 86.

16 Ziemba, Sztuka Burgundii, t. 2, 186. 
w warsztatach włoskich i niemieckich. Na terenie Italii, już na początku XV stulecia, zaczęła się stopniowo kształtować formuła tzw. wczesnorenesansowej zbroi płytowej włoskiej, z charakterystycznymi połyskującymi płaszczyznami, o dużych, rozbudowanych w skrzydła, asymetrycznych naramiennikach i umiejętnie wkomponowanych w płytowy garnitur elementach kolczugi. Całości dopełniał typ hełmu, określany jako przyłbica nowszego typu, nazywany w literaturze bronioznawczej $\operatorname{armet}^{17}$. Armet to najdoskonalszy technicznie hełm zamknięty z okresu późnego średniowiecza. Dzwon hełmu otwierał się na boki, zasłona uzyskała w drugiej dekadzie XV w. optymalny, ostry kształt dziobu (chociaż ikonografia przedstawia również inne, bardziej opływowe kształty). Walory ochronne armetu wzmacniał doczepiany, mocowany za pomocą tarczki potylicznej, dodatkowy podbródek. Pierwsze wizerunki wczesnych armetów z zasłoną, a także przykłady prototypów stylistycznych zbroi włoskiej można obejrzeć na miniaturach włoskiego kodeksu dotyczącego sztuki walk Flos Duelatorum z 1410 r., autorstwa Fiore Dei Liberiego ${ }^{18}$.

Styl płatnerstwa niemieckiego był oparty na innych założeniach estetycznych. Podstawą była symetria, a także zdobnictwo w postaci grani oraz kanelowaniach powierzchni. Optymalny wygląd swoich produktów płatnerze niemieccy uzyskali $\mathrm{w}$ drugiej połowie XV stulecia ${ }^{19}$. Typowym hełmem występującym w komplecie tzw. zbroi gotyckiej była salada $\mathrm{z}$ dodanym podbródkiem w wersji z zasłoną lub bez. Charakterystyczne były tu trzewiki o bardzo długich nosach, granione napierśniki, naramienniki złożone $\mathrm{z}$ wielu folg, a także kwieciście wyglądające tarczki opachowe, czego na ogół nie znajdujemy w stylu italskim. Na wczesnym etapie rozwoju stosowano również przyłbice grand basinet, które pokazują rozmaite przykłady ikonografii z terenów Niemiec - od nagrobków po miniatury manuskryptów z pierwszej połowy $\mathrm{XV}$ w. ${ }^{20}$ We wczesnym etapie rozwoju zbroi gotyckiej podstawową różnicą pomiędzy zbroją niemiecką a włoską był napierśnik skrzyńcowy kastenbrust, który wykorzystywano od około $1420 \mathrm{r}$.

Aby nieco przybliżyć wizerunek militariów ukazanych przez van Eycka, należy pokrótce opisać uzbrojenie używane w jego czasach na terenie Niderlandów i Burgundii. W uzbrojeniu zaczepnym nie widać istotnych różnic w stosunku do innych rejonów Europy. Główną bronią konnicy tego czasu była oczywiście kopia, ale na miniaturach pojawiła się również włócznia o krótkim i cienkim drzewcu, jakby odpowiednik litewskiej sulicy. Broń drzewcowa piechoty wykazuje w tym czasie

$17 \quad$ Żygulski, Broń $w$ dawnej Polsce, 107.

18 Fotokopia kodeksu z kolekcji Pissaniego-Dossiego sprzed jego zaginięcia, wykonana w 1902 przez historyka Francesco Novatiego, https://www.accademianazionaledischerma.it/.../download. aspx?, dostęp: 11 VI 2018.

19 Uzbrojenie w Polsce średniowiecznej 1350-1450, red. Andrzej Nadolski (Łódź: P.A.N., 1990), 72.

20 Termin grand basinet jest zdaniem autora tekstu bardziej precyzyjny niż polski odpowiednik „przyłbica starszego typu”, gdyż oznacza model hełmu o podbródku i nakarczku płytowym, natomiast określenie mianem „przyłbicy starszego typu” może również dotyczyć odmian bez tych elementów, a jedynie $\mathrm{z}$ doczepionym czepcem kolczym. 
mnogość odmian halabard, szydeł, glewii, gizarm i innych rozmaitych kombinacji ostrzy oraz kolców. Należy pamiętać, że miasta flandryjskie to jeden z ośrodków rozpoczętego w XIII stuleciu europejskiego renesansu piechoty. Używanie rozmaitych maczug i młotów na długim drzewcu miało wśród piechurów flamandzkich długą tradycję. Broń miotająca - kusza i pod wpływem angielskim długi łuk - także należały do flamandzkiego arsenału z pierwszej połowy XV stulecia (świetny przykład długiego łuku pokazuje miniatura Św. Sebastian Mistrza Delfckich Grisaillów z Godzinek-Loftie, datowana na lata 1440-145021. W drugiej połowie XIV stulecia i w XV w. coraz większą popularność zyskiwała ręczna broń palna - piszczele, później hakownice i około połowy XV w. rusznice. Dominującą wśród rycerstwa bronią sieczną nadal pozostawały miecze późnośredniowieczne o rękojeściach jedno--, półtora- lub dwuręcznych. Oprócz nich jako broni bocznej używano, tak jak w całej ówczesnej Europie, licznych odmian kordów i tasaków. $\mathrm{W}$ arsenale konnicy i piechoty nadal pojawiała się także broń obuchowa w postaci toporków rycerskich, nadziaków i buzdyganów. Krótką broń białą stanowiły puginały jedno lub obosieczne: nerkowe, tarczowe, basilardy i inne odmiany.

Uzbrojenie ochronne, jakie ukazuje ówczesna ikonografia z terenów niderlandzko-burgundzkich, pozostawało pod silnym wpływem płatnerstwa niemieckiego, o czym świadczą ukazane typy napierśników skrzyńcowych z długimi szorcami, które zaczęto w latach dwudziestych lub na początku lat trzydziestych XV stulecia uzupełniać dodatkowymi płytkami osłaniającymi uda - taszkami. Przy zbrojach, które można oglądać choćby na nagrobkach z terenów Niderlandów, często występują tarczki ochraniacze opachowe i nałokietne. Ikonografia $\mathrm{z}$ lat trzydziestych i czterdziestych XV w. ukazuje również zbrojnych w bombiastych napierśnikach, $\mathrm{z}$ charakterystycznymi kloszowatymi szorcami, czasem mającymi wycięcie z przodu, ale również i w napierśnikach z rozchodzącymi się graniami, które jako kolejny element mody w płatnerstwie północnoeuropejskim weszły w użycie około $1430 \mathrm{r}$. Na zbroje nakładano czasem szatę typu tabard. Oprócz kirysów płytowych noszono również inne napierśniki w postaci kirysów folgowych (czyli płatów) i przede wszystkim brygantyny, popularne także w późniejszym okresie. Oczywiście w całym omawianym okresie nadal pozostawała w użyciu kolczuga, czy to w formie koszul z długimi rękawami, czy też kolczych kapturów, jak również jako pewne zabezpieczenie miejsc na ciele, które nie były chronione elementami zbroi płytowej. Ikonografia niderlandzko-burgundzka ukazuje ponadto elementy płytkowe zbrojnikowe już w okresie wcześniejszym od omawianego. Natomiast w późniejszym czasie (czyli po $1441 \mathrm{r}$.) pojawiły się w niej zbroje lub pewne ich elementy nawiązujące do płatnerskiej estetyki południa Europy, jak zbroje włoskie lub elementy zbroi w postaci dużych naramienników czy też dwuczęściowych napierśników. Jako przykłady wizerunków

${ }^{21}$ The Walters Art Museum, Baltimore, nr inw. W.165.120V, fol. 120, http://art.thewalters.org/ detail/1147/st-sebastian-2/, dostęp: 11 VI 2018. 
nawiązujących do stylu lombardzkich zbroi można wymienić dzieła: Petrusa Christusa Sąd Ostateczny z 1452 r. oraz brukselską tapiserię z 1461 r. - Sprawiedliwość cesarza Trajana i Sprawiedliwość hrabiego Herkibalda, wykonaną według wcześniejszego dzieła Rogiera van der Weydena ${ }^{22}$. Niektóre z miniatur kroniki Brabantsche Yeesten, datowanej na lata 1440-1450, również pokazują zbroje w podobnym stylu, o czym mogą świadczyć wyglądające na asymetryczne spore naramienniki ${ }^{23}$. Miniatury $\mathrm{z}$ tego cyklu zawierają mnogość form uzbrojenia, w tym różne odmiany hełmów: łebki o bardziej kulistych, zaokrąglonych dzwonach i bardziej szpiczaste, $z$ dodanymi stalowymi podbródkami, hełmy sferyczne $\mathrm{z}$ dodatkowymi tarczkami przyusznymi, salady z zasłoną, kapaliny $\mathrm{z}$ wąskim rondem, hełmy turniejowe $\mathrm{z}$ kratownicą oraz żabie pyski, przyłbice typu grand basinet. Grand basinet można także znaleźć na pieczęci księcia Filipa III Dobrego. Salada stała się jednym z podstawowych hełmów armii burgundzkiej, do której przynależały kontyngenty flandryjskie. Jeszcze w latach trzydziestych XV w. były noszone przyłbice typu psi pysk. Mogły się wówczas pojawiać także włoskie armety, chociażby ze względu na kontakty Burgundii i miast flamandzkich z miastami Italii. Nie jest wykluczone, że przyłbica tego typu została pokazana na miniaturze wspomnianego powyżej cyklu Brabantsche ${ }^{24}$. Płatnerskie wpływy stylistyczne docierały również z sąsiedniej Francji. Ikonografia francuska $\mathrm{z}$ tego okresu pokazuje bowiem elementy uzbrojenia związane z Italią, czego dowodem jest m.in. manuskrypt Un tres notable Livre nommé Guirona le Courtois (Roman de Guiron de Courtois), dekorowany w latach dwudziestych-trzydziestych XV w..$^{25}$

O tym, że płatnerze niderlandzcy wykuwali zbroje w różnej stylistyce może pośrednio świadczyć korespondencja angielskiego rycerza Johna Pastona z brugijskim płatnerzem Martinem Rondellem, dotycząca pełnego kompletu zbroi płytowej. Płatnerz domagał się doprecyzowania zamówienia, z czego można wnioskować, że ówcześni rzemieślnicy byli zaznajomieni z różnymi stylami uzbrojenia ${ }^{26}$.

Ważnym dopełnieniem ochronnego uniformu wojowników były oczywiście tarcze. Na rycerskich nagrobkach niderlandzkich z tego okresu można znaleźć niewielkie tarcze o kształcie prostokąta, z zaokrągloną dolną krawędzią, bądź też

22 Sąd Ostateczny z 1452, Berlin, Staatliche Museen, Gemäldegalerie; Sprawiedliwość cesarza Trajana i Sprawiedliwość hrabiego Herkibalda, Berno, Historisches Museum; Ziemba, Sztuka Burgundii, t. 2, 526, il. 700 oraz 259, il. 285.

${ }_{23}$ Zob. https://commons.wikimedia.org/wiki/Category:Brabantsche_yeesten”|h, https:// commons.wikimedia.org/wiki/Category:Brabantsche_yeesten, http://manuscriptminiatures.com/ search/?manuscript=4530, dostęp: 11 VI 2018.

${ }^{24}$ Brabantsche Yeesten (Bruksela, Koninklijk Bibliotheek van België, ms. Bruxellensis IV 684, fol. 100), http://manuscriptminiatures.com/4530/8533/, dostęp: 11 VI 2018.

25 Manuskrypt Guirona le Cortois, Bibliothèque Nationale de France w Paryżu (ms. Français 356), folio 184r http://manuscriptminiatures.com/5168/16174/, dostęp: 11 VI 2018.

26 Norman Davis, Colin Richmond, Paston letters and papers of the fifteenth century, Part II (Oxford: University Press, 2004), 409, tekst nr 769. 


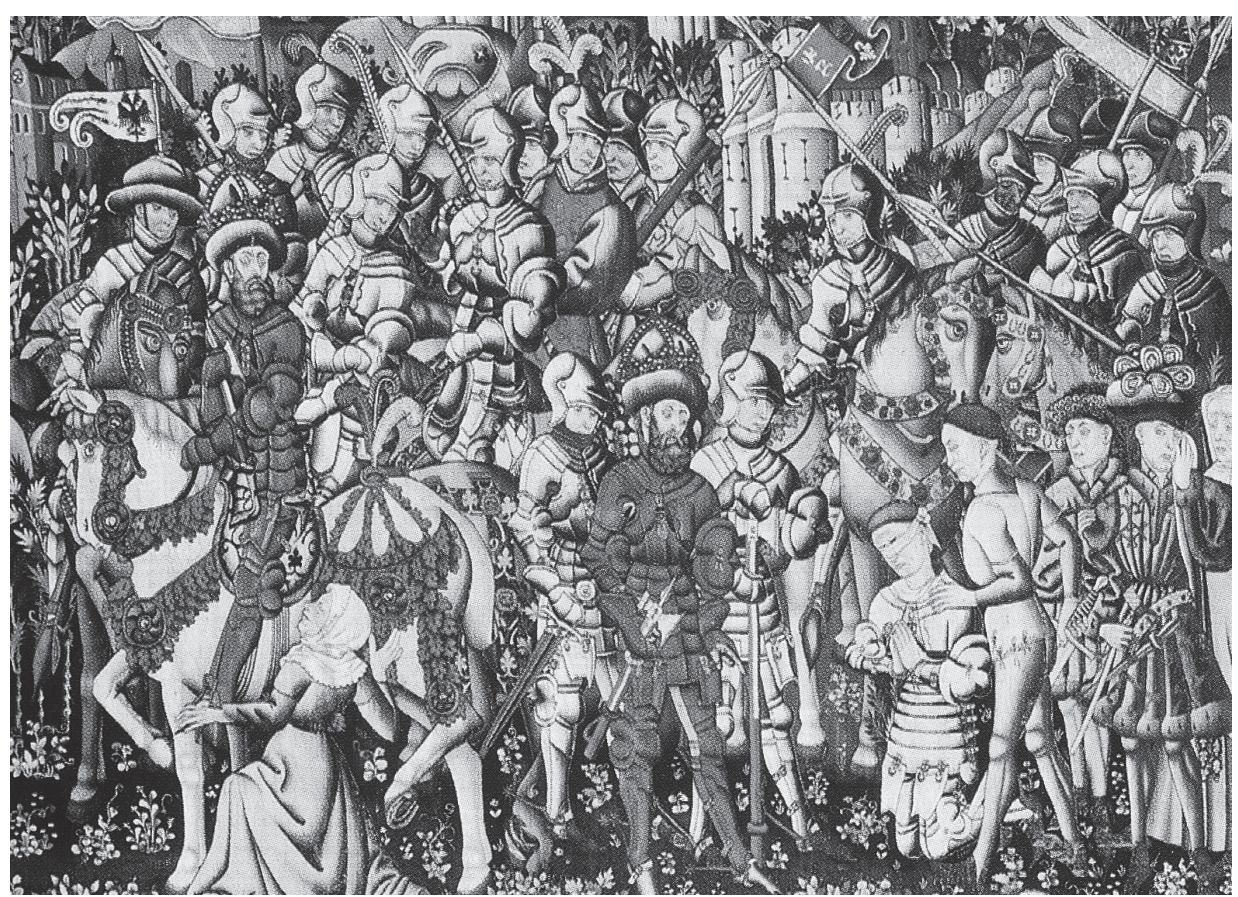

Fot. 1. Tapiseria Sprawiedliwość Trajana i Sprawiedliwość Herkinbalda (fragment), Historisches Museum, Berno

Źródło: https://pl.wikipedia.org/wiki/Sprawiedliwo\%C5\%9B\%C4\%87_Trajana_i_Sprawiedliwo\%C5\%9B\% C4\%87_Herkinbalda\#/media/File:After_Rogier_van_der_Weyden_-_The_Justice_of_Trajan_and_Herkinbald. jpg, dostęp: 11 VI 2018.

niewielkie tarcze zbliżone kształtem do trójkąta o nieco zaoblonych bokach ${ }^{27}$. Oprócz tych typów, wśród piechoty, były w użyciu duże pawęże oraz dość często charakterystyczne tarcze posiadające dużą okrągłą wypukłość pośrodku. Ponadto rycerze niderlandzcy wykorzystywali tarcze jeździeckie o kształcie prostokąta, z wygiętymi płaszczyznami, czasem $\mathrm{z}$ wycięciem na kopie. W ikonografii można również znaleźć wizerunki puklerzy podobnych do tych przedstawionych przez van Eycka.

Na koniec tego bardzo skróconego opisu uzbrojenia zobrazowanego we wczesnopiętnastowiecznej ikonografii, z naciskiem na uzbrojenie ochronne, warto jeszcze wspomnieć o możliwych wpływach angielskich - co zostanie podkreślone przy omawianiu nowojorskiego dyptyku Ukrzyżowane i Sad Ostateczny. Dalsze analizy wykażą również istnienie na terenie Niderlandów, w okresie drugiej i trzeciej ćwierci XV stulecia, odrębnego, lokalnego stylu płatnerskiego, będącego mieszanką wpływów italskich i niemieckich.

$27 \mathrm{http}: / /$ effigiesandbrasses.com/search/?name $=\& \operatorname{tags}=\&$ country $=12 \&$ country $=9 \& \operatorname{country}=2$ 4\&year_end=\&institution=\&year=\&page=6, dostęp: 11 VI 2018. 


\section{Poliptyk Gandawski}

Z dwunastu kwater otwartego Poliptyku interesujące dla tematu rozważań są dwie z nich. Druga kwatera od lewej, umiejscowiona w górnym rzędzie, przedstawia chór anielski. Jednym z elementów namalowanych w tej kwaterze jest mebel, ambonka szafkowa z pulpitem. W dolnej jego części znajduje się postać archanioła Michała zabijającego trzygłowego węża-smoka.

W kwaterze Rycerzy Chrystusowych - prezentują się oni okazale - w zbrojach płytowych, z tarczami i z drzewcami chorągwi w dłoniach. Są przedstawieni bez hełmów, z odkrytymi głowami. Włócznie, do których przymocowane zostały chorągwie, mają groty o różnych kształtach. Włócznia-proporzec rycerza ukazanego na pierwszym planie ma dość wąski, lancetowaty grot z granią, osadzony na niezbyt długiej tulei. Drzewce chorągwi drugiego z rycerzy wieńczy grot o liściu lancetowatym z granią, nieco szerszy od poprzedniego i jest osadzony na długiej tulei. Tego typu groty były w niektórych rejonach Europy, np. na Śląsku, w użyciu jeszcze w następnym stuleciu (groty włóczni z Piekar Wielkich) ${ }^{28}$. Z kolei włócznia (kopia) ostatniego jeźdźca ma zakończenie w postaci piramidalnego grotu na długiej tulei. Grot ten jest dość nietypowy i przypomina bardziej grot bełtu do kuszy niż grot włóczni. Nie jest wszakże wykluczone, że tak właśnie wyglądały niektóre groty ówczesnych kopii rycerskich na terenie Burgundii i Niderlandów. Przekrój liścia, sądząc po piramidalnym kształcie, byłby zapewne czworokątny, a takie groty kopii - masywne, krępe i czworokątne w przekroju liście - służyły do przebijania osłon płytowych ${ }^{29}$. Oczywiście, można takie groty rozpoznać również po szerokiej tulei, którą osadzało się na grubych drzewcach. Niestety nie udało mi się znaleźć jak dotąd bliższej analogii dla tego specyficznego grotu z Poliptyku Gandawskiego. Istnieje jeszcze możliwość mocowania tego typu grotów tylko na drzewcach proporców-chorągwi.

Pierwszy z trzech rycerzy, siedzący w typowym bojowym, kopijniczym siodle z okutymi metalem, wysokimi łękami, ma założony płytowy kirys z napierśnikiem o kubicznej formie. W literaturze bronioznawczej określa się go jako napierśnik skrzyńcowy (niem. Kastenbrust) $)^{30}$. Jak już wspomniano, wcześniej napierśniki te pojawiły się w Europie po roku $1420 \mathrm{i}$ były wytworem płatnerstwa niemieckiego. Zdobyły popularność w krajach niemieckich, a także szerzej - na obszarach na północ od Alp. Burgundia, północna Francja i Niderlandy stanowiły strefę ścierania się wpływów Południa, czyli płatnerstwa Italii oraz Północy, a więc płatnerstwa niemieckiego (jednak do tych rozgraniczeń należy podejść dość ostrożnie). Podobny kastenbrust, lecz pokazany w całej okazałości z sześciofolgową szorcą i z dodatkowymi płytkami

28 Lech Marek, „Broń biała na Śląsku XIV-XVI wiek”, Vratyslavia Antiqua 10 (2008): 299, il. 126.

29 Por. groty kopii z Nysy - lancetowaty z granią i szeroka tuleja, Karkonosze i Wąsosza wszystkie z przeł. XIV/XV w. - Marek, Broń biała, 92 oraz il. na 303, ryc. 130a-c.

30 Uzbrojenie w Polsce średniowiecznej 1350-1450 (dalej UwPś), 72. 
chroniącymi uda, można oglądać na terenie Niderlandów na nagrobku Gisbrechta van Bronckhorsta, z około 1429 r., znajdującym się w Batenburgu (Geldria) ${ }^{31}$. Kolejną analogię może stanowić kastenbrust z długim, pięciofolgowym fartuchem, przedstawiony na wspomnianej miniaturze ukazującej św. Sebastiana w manuskrypcie z niderlandzkich Godzinek (Loftie Hours), datowanej na lata 1440-50. Dysponujemy ponadto wczesnymi przedstawieniami tego rodzaju napierśników z terenów Niderlandów, a ukazanymi jeszcze bez długiej szorcy. Przykładem mogą być napierśniki namalowane na kolejnych stronicach Godzinek ${ }^{32}$.

Napierśnik skrzyńcowy z długą szorcą, jaki nosi drugi ze zbrojnych Milites Christi, van Eyck uwiecznił również w miniaturze Godzinek Turyńsko-Mediolańskich - Modlitwa na plaży. Wśród orszaku przedstawionego tam po lewej stronie jedzie konny rycerz w pełnej zbroi płytowej i w grand basinecie na głowie. Kastenbrusty można znaleźć również na innych dziełach sztuki tego okresu, w tym na obrazach Konrada Witza, np. postać Sabothaja/Sibbekaja z Oltarza Zwierciadła Zbawienia z lat 1435-40 (Kunstmuseum, Bazylea) ${ }^{33}$. Również Ołtarz Albrechta II z Klosterneunburg ukazuje zbroje z bardzo długimi szorcami, rozciętymi z przodu oraz napierśnik skrzyńcowy ${ }^{34}$. Kolejne wyobrażenia można znaleźć w niemieckim kodeksie poświęconym Wojnie Trojańskiej - Konrada z Würzburga, z $1441 \mathrm{r}^{35}$ Można jeszcze dodać, że ten typ napierśników pojawił się również na ziemiach polskich w latach trzydziestych $\mathrm{XV} \mathrm{w} .^{36}$

Wracając do omawianego rycerza z Poliptyku Gandawskiego, spod napierśnika zbroi wystaje szata, więc osłona podbrzusza jest niewidoczna. Naramienniki zbroi składają się z większej płyty naramiennej oraz czterech zmniejszających się folg, spod których opadają zielone rękawy szaty cottehardie. Szata nieco odsłania metalową ochronę przedramienia, a także płytowe, jednopalczaste rękawice mitynki o dość dużym mankiecie. W miejscu palców osłonę stanowią dwie metalowe folgi. Spod fantazyjnej szaty wystaje miseczka nakolanka o dużym skrzydełku i trzech dolnych folgach. Dolna część nóg jest chroniona przez płytowe dwuczęściowe nagolennice i widoczny trzewik, złożony z siedmiu folg. Na lewym ramieniu rycerz ma zawieszoną niewielką, odkutą z metalu tarczę jeździecką

31 Zob. http://effigiesandbrasses.com/5604/20035/ oraz publikacja: Fran Allen Greenhill, Incised Effigial Slabs: A Study of Engraved Stone Memorials in Latin Christendom, c. 1100 to C. 1700 . Two volumes (London: Faber \& Faber, 1976).

32 Fol. 50v, 58r, 111v, Morgan Library, Nowy Jork, http://manuscriptminiatures.com/ search/?manuscript=4707, dostęp: 11 VI 2018.

33 Ołtarz Zwierciadła Zbawienia z lat 1435-40 (Kunstmuseum, Bazylea); David Edge, Miles Paddock, Arms and Armour in The Medieval knights (Greenwich: Bison Books 1988), il. 95.

34 UwPś, 526, il. 112.

35 Germanisches Nationalmuseum w Norymberdze, GNM Hs998, fol. 26v, dlib.gne.de/item/ Hs998/html, aufnahme 428/206r, 70/26v - widać tam również szatę, wystającą spod naramienników, podobnie jak na Ottarzu Gandawskim.

36 Piotr Andrzej Nowakowski, Arsenały domowe rycerstwa polskiego w średniowieczu (Toruń: Adam Marszałek, 2006), 127-128, tab. 27. 
z wycięciem na kopię. Tarcza posiada pionową, biegnącą przez środek grań. Boki tarczy są na górnych i dolnych narożach fantazyjnie wywinięte. Przy prawym boku rycerza zwisa trzymany w pochwie puginał nerkowy, który był używany w Europie już od XIII stulecia.

Drugi rycerz od lewej nosi napierśnik skrzyńcowy z pionowymi kanelowanymi (?) liniami-graniami i długą szorcą. Folgowy fartuch jest złożony z pięciu pasów oraz z doczepionych dodatkowych tarczek osłaniających uda. Kastenbrust z pionowymi graniami można podziwiać na niemieckim nagrobku Grafena von Öttingen w kościele w Kircheim am Ries, w Badeni-Wirtembergii ${ }^{37}$. W uzbrojeniu drugiego z Milites Christi van Eycka widoczne są naramienniki złożone $\mathrm{z}$ większej płyty i z trzech mniejszych folg. Opachy zostały przykryte tkaniną, ale częściowo widać zarękawia zbroi i płytową rękawicę. Rękawica różni się od omówionej wcześniej i nie posiada folg, jest konstrukcyjnie homogeniczna. Wykazuje pewne podobieństwo do rękawicy ze zbroi z zamku Churburg, a wykutej około $1420 \mathrm{r}^{38}$ Inne analogie można znaleźć na niemieckich nagrobkach i rzeźbach, np. Der Bömische Konig Hansa Multschera - fasada ratusza w Ulm (ok. 1427-1433) ${ }^{39}$. Kolejną bliższą analogię może stanowić inna rękawica ze zbrojowni zamku Churburg, być może pochodząca z Innsbrucku ${ }^{40}$. Obie rękawice należą do nowszej generacji, która w tym czasie wypiera rękawice klepsydrowe będące w użyciu na terenie Europy od drugiej połowy XIV w. Z osłon nóg bejgwantów na obrazie widoczny jest jedynie niewielki fragment płytowych nabiodrków. Na lewym ramieniu wojownik ma zawieszoną tarczę z wycięciem na kopie. Tarcza jest zbliżona kształtem do prostokąta o wyraźnie pochylonej części górnej i dolnej. Tarczę o podobnym kształcie artysta umieścił też na plecach św. Jerzego w Madonnie van der Paele.

Trzeci z rycerzy został pokazany w taki sposób, że z uzbrojenia ochronnego wystaje tylko fragment napierśnika oraz kołnierz kolczy przy szyi. Ostatnim $\mathrm{z}$ przedstawionych elementów uzbrojenia jest tarcza na lewym ramieniu. Artysta namalował wygiętą tarczę z wycięciem na kopię i być może, jak w przypadku pierwszego rycerza, również odkutą z metalu. Tarcza ma dwie granie biegnące pionowo. Pewne ogólne podobieństwo można dostrzec w tarczy namalowanej przez van Eycka w Tryptyku Drezdeńskim.

Archanioł Michał z reliefu na tablicy Chóru Aniołów trzyma w prawej dłoni miecz, którym przebija wielogłowego smoka. Miecz ma dwuręczną rękojeść, prosty jelec i dosyć szeroką klingę, jednak nie widać dokładnie głowicy ani jego sztychu.

37 http://effigiesandbrasses.com/3015/6327/, dostęp: 11 VI 2018.

38 Zamek Churburg, nr inw. Ch 18; G.O. Trapp, M. Scalini, L'Armeria Trapp di Castel Coira. The Armoury of the Castle Churburg, Die Churburger Rüstkammer, London 1996, I, 73, il. 3. e castle Churburg (London: Magnus, 1996), 73, il. 3.

39 Obraz znajduje się w Ulmer Museum. Geschichte der deutschen Kunst, red. Ernst Ulmann (Leipzig: E.A. Seemann, 1981), il. 145.

40 Claude Blair, European Armour circa 1066 to circa 1700 (London: Batsford/Macmillan, 1959), rosyjskie wydanie: Rycarskije dospechy evropy (Moskwa: Centroligraf, 2006), 234, il. 112-113. 
W lewej dłoni trzyma okrągłą tarczę-puklerz z mocnym wybrzuszeniem. Bardzo bliską analogię stanowi tarcza-puklerz archanioła Michała ze sceny Sądu Ostatecznego w dyptyku nowojorskim van Eycka. Obie tarcze mają pośrodku znaczną wypukłość i są bogato zdobione.

Najciekawszy jest ubiór ochronny archanioła. Nosi na głowie hełm z rondem, szerszym z przodu, jego dzwon jest sferyczny, dodatkowo zdobiony pręgami i kamieniami. Został zaopatrzony w dziwny grzebień biegnący aż na rondo. Na szczycie dzwonu umieszczono niewielki krzyż. Naramienniki zbroi składają się z jednej większej płytki naramiennej oraz z kilku rzędów prostokątnych, metalowych bądź skórzanych pasków, które wyglądają podobnie do przedstawionych przez van Eycka w Madonnie van der Paele oraz w Tryptyku Drezdeńskim. Takie naramienniki z wystającymi paskami skórzanymi występują nie tylko w ikonografii bizantyjskiej i bałkańskiej, ale również w zachodnioeuropejskiej, czego dowodem mogą być miniatury francuskie. Interesującym przykładem jest wspomniany już rękopis Roman de Guiron le Courtois, powstały raczej około roku 1420 lub, sądząc po przedstawionym uzbrojeniu, w latach trzydziestych XV w. ${ }^{41}$ Ochrona tułowia również wzbudza zainteresowanie i zdradza podobieństwo do wspomnianych powyżej późniejszych dzieł malarza. Przedstawienie nie pozwala na precyzyjną identyfikację typu napierśnika, który posiada dwa medaliony w kształcie kwiatów. Widoczny fragment tylnej części kirysu przywodzi na myśl ten św. Jerzego ze wspomnianej Madonny van der Paele. Wyraźnie natomiast widać osłonę podbrzusza, czyli szorcę, wykonaną z jednego rzędu prostokątnych, dłuższych płytek. Poniżej niej występuje jeszcze jeden rząd skórzanych, prostokątnych pasków.

Nogi archanioła są osłaniane przez żelazne nakolanki i nagolennice. Te drugie wyglądają na wykonane ze skóry bądź innego materiału organicznego lub ewentualnie metalu. Są dodatkowo wzmocnione listwami. Nie sposób nie odnieść wrażenia pewnej stylizacji modelowania form na bizantyjskie lub wręcz późnoantyczno-rzymskie. W stylu bizantyjskim, zwłaszcza na wizerunkach świętych wojowników, występowały elementy pancerzy płytkowych oraz rzędy skórzanych pasków przy naramiennika i osłonie podbrzusza ${ }^{42}$. Pewne podobieństwa można również znaleźć na wizerunkach powstających w kręgu sztuki włoskiej już od XII w. ${ }^{43}$

Podsumowując, w przedstawieniach Rycerzy Chrystusowych $z$ Poliptyku Gandawskiego można zaobserwować uzbrojenie silnie powiązane z niemiecką modą płatnerską. Lata dwudzieste i trzydzieste XV w. to okres coraz wyraźniejszego kształtowania się mody gotyckiej w płatnerstwie tej części Europy, czego przykładem są wspomniane napierśniki skrzyńcowe. Trudno jest czasem precyzyjnie

${ }^{41}$ Roman de Guiron le Courtois, BNF, Français 356; wizerunki tego typu można znaleźć na fol. 127v, 164v, 164r i kilku innych - http://manuscriptminiatures.com/search/?manuscript=5168 oraz manuskrypt w pełnej wersji na stronie Francuskiej Biblioteki Narodowej - http://gallica.bnf. fr/ark:/12148/btv1b8514422s/f1.planchecontact.r=.langEN, dostęp: 11 VI 2018.

42 David Nicolle, Byzantine Armies 1118-1461 (London: Osprey Publishing, 1995), il. 22-23.

43 Nicolle, Arms and Armour in the Crusading era, t. 2 (London: Greenhill Books, 1999), il. 469, około 1240 r., il. 598A oraz s. 479, lata 1330-50, il. 657A, 657e, 657g oraz s. 494, wiek XII, il. 696 oraz 697. 

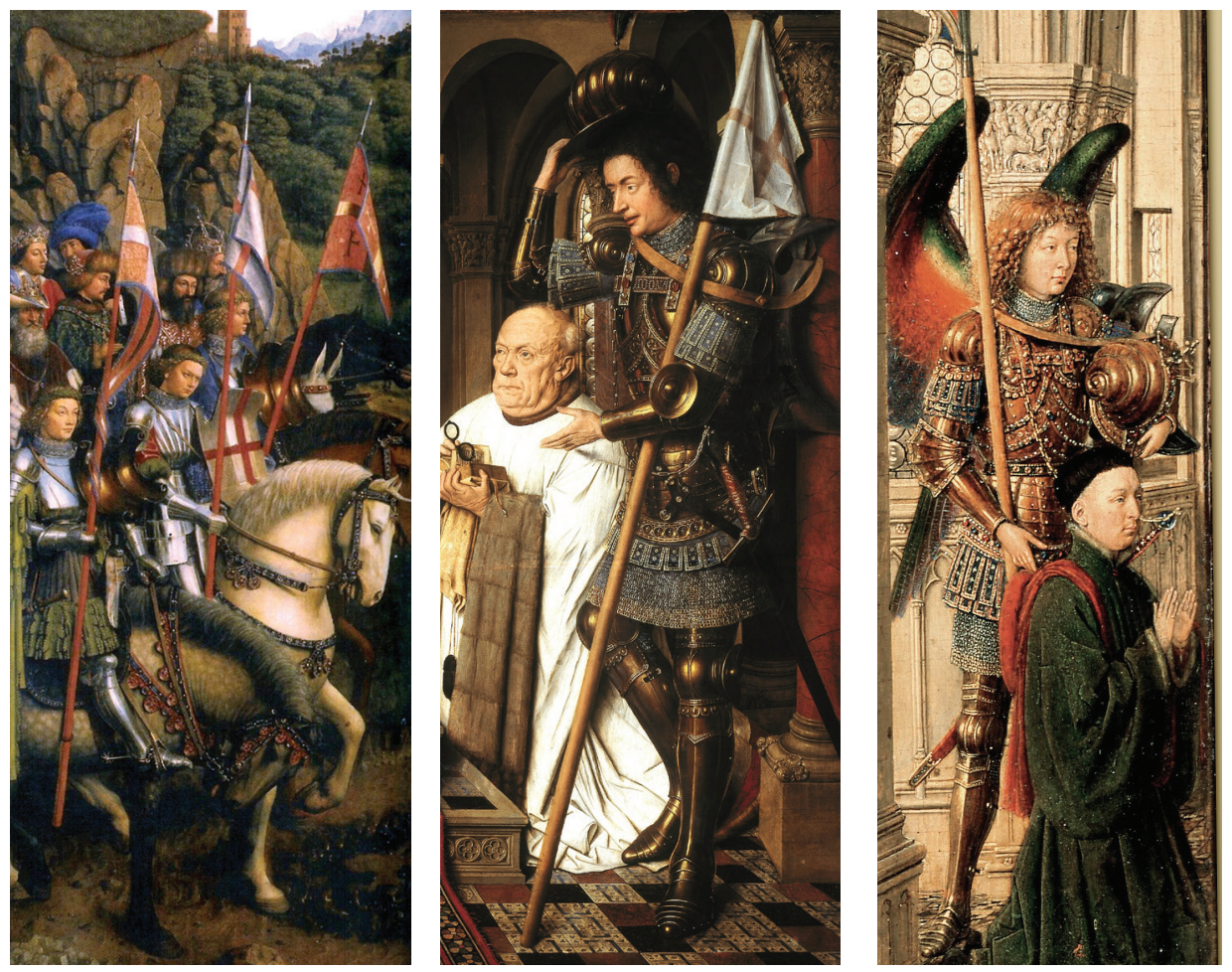

Fot. 2. Fragment Ottarza Gandawskiego - Milites Christi (1432), The Saint Bavo Cathedral, Ghent, fot. ze zbiorów autora

Fot. 3. Fragment Madonny kanonika van der Paele (1434-36), Groeningemuseum, Brugia

Źródło: https://pl.wikipedia.org/wiki/Madonna_kanonika_van_der_Paele\#/media/File:Jan_van_Eyck_069.jpg, dostęp: 11 VI 2018.

Fot. 4. Fragment Tryptyku Drezdeńskiego (1437), Gemäldegalerie Alte Meister, Dresden

Źródło: https://upload.wikimedia.org/wikipedia/en/c/c7/Dresden_Triptych_Detail_Archangel_Michael_with_ Donor_1.jpeg, dostęp: 11 VI 2018.

rozgraniczyć strefy silniejszych wpływów włoskich lub niemieckich. Całość wizerunków z kwatery zajmowanej przez Rycerzy Chrystusa należy zakwalifikować jako wierne odzwierciedlenie uzbrojenia z epoki. Pewne zastrzeżenia mogą budzić niektóre elementy ochronne $\mathrm{u}$ archanioła Michała (hełm i zbroja). Nie jest to wykluczone, że jakieś bliskie analogie dla owego hełmu zostaną znalezione w bardzo obszernej ikonografii europejskiej, na razie jednak trudno jest sprawę jednoznacznie rozstrzygnąć.

Interesujący z punktu widzenia samej historii sztuki może być wątek „bizantynizacji” - tj. nawiązań, mniej lub bardziej świadomych, do form uzbrojenia wschodniego, bizantyjsko-bałkańskiego (vide nagolenice archanioła z reliefu lewej tablicy Chór aniołów). Ten rodzaj stylizacji i archaizacji mający zapewne ewokować wrażenie, że widz ogląda strój starodawny, „starożytny”, prachrześcijański, a zarazem 
powszechny, uniwersalny, panchrześcijański, wpisywałby się w silną u van Eycka i malarzy flamandzkich XV w. tendencję do podkreślania bizantyjskich (a konkretnie: italo-bizantyjskich) korzeni sztuki religijnej. Źródłem sztuki ukazującej i uobecniającej sacrum - „,́więtych obrazów”, „cudownych wizerunków” - miały być włosko-bizantyjskie ikony sprowadzane z Italii lub w Italii otoczone kultem pielgrzymkowym (cudowne wizerunki Świętego Oblicza Chrystusa, kultowe cuda czyniące przedstawienia Chrystusa Umęczonego, różne warianty Madonny św. Łukasza itp. ${ }^{44}$.

\section{Madonna van Der Paele}

Madonna kanonika Jorisa van der Paele została namalowana w latach 1434-1436. Po bokach tronującej Madonny stoją: po lewej stronie - św. Donacjan, patron brugijskiej kolegiaty Sint-Donaas, a po prawej - św. Jerzy, patron imienny fundatora, którego tu poleca opiece Marii i Chrystusa, a zarazem patron rycerstwa. I to on będzie przedmiotem mojej analizy.

Święty odziany jest w charakterystyczną zbroję płytową. Prawą dłonią zdejmuje z głowy hełm w geście pełnym czci wobec Marii i małego Jezusa, lewą przytrzymuje drzewce chorągwi. Ma na plecach tarczę z widocznym wycięciem służącym do podtrzymywania kopii w trakcie szarży. Przy lewym boku Jerzego widać przypasany miecz, którego głowica łączy się łańcuszkiem z płytą napierśnika zbroi. Miecz jest schowany w pochwie. Rękojeść jest dwuręczna, jelec wygląda na typ 5 według systematyki Oakeshotta i Głoska ${ }^{45}$. Głowica miecza może być zaliczona, sugerując się wspomnianą typologią, do typu T lub F. Przedstawienie nie daje jednak pełnej możliwości jej określenia.

Zbroja okrywa całe ciało rycerza. Tors chroni kirys płytowy z szorcą osłaniającą podbrzusze. Napierśnik kirysu jest bogato zdobiony i posiada kwiatowo wyglądające mocowanie do łańcucha. Widoczny jedynie fragment naplecznika wygląda jakby był zmontowany z kilku zachodzących na siebie dachówkowato, łukowato wygiętych płyt. Interesujące jest to, że w pewnym momencie napierśnik płytowy przechodzi w konstrukcję wykonaną z rzędów poziomych nitowanych zbrojników. Przychodzi na myśl jeszcze jedna hipotetyczna możliwość konstrukcyjna, że ów kirys został nałożony na konstrukcję płytkową. U dołu szorcy widać zawieszony pas rycerski, wykonany częściowo z metalowych plakietek. Poniżej widnieje rząd skórzanych (?), prostokątnych pasków ułożonych pionowo. Niżej wystaje kolczuga dochodząca do połowy uda.

${ }_{44}$ O tym zjawisku zob.: Ziemba, Sztuka Burgundii, t. 2, 726-736; T.H. Borchert, "Memling and the Byzantine tradition", w Hans Memling and the Art of Private Devotion in the 15th-and Early 16th-Century Netherlands, sympozjum, Muzeum Narodowe w Gdańsku (1.12.2017), Gdańsk (w druku).

45 Marian Głosek, Miecze środkowoeuropejskie X-XV w. (Warszawa: Wydawnictwo Geologiczne, 1984), 27; Ewart Oakeshott, Records of Medieval Sword (Suffolk: Boydell Press, 1991), reprinted 2000, 9. 
Ręce wojownika są chronione przez muszlowate w kształcie naramienniki, spod których wystają dwa rzędy pionowo ułożonych, prostokątnych pasków. Dopiero teraz widać fragment opachy płytowej, nałokietniki z okrągłą tarczką, złożone z miski i kilku folg, oraz płytowe zarękawia, pokazane bardzo realistycznie wraz z rzeczywistym sposobem ich zapinania na sprzączki. Nogi chronią pełne, płytowe bejgwanty. Na obrazie widać fragment nabiodrków, nakolanki z bocznymi zewnętrznymi i wewnętrznymi okrągłymi tarczkami, złożone z miseczki oraz dolnej płytki. Dół nóg jest chroniony przez nagolennice oraz folgowe, żelazne obuwie-trzewiki, zmontowane z ośmiu widocznych pasów metalu.

Bardzo interesujący jest hełm św. Jerzego. Jego dzwon ma muszlowatą formę, podobnie jak naramienniki zbroi. W górnej jego części jest umiejscowiona niewielka sterczynka i mocowanie do pióropusza. Z przodu dzwonu znajduje się wydatny daszek. Bardzo podobny hełm artysta przedstawił w następnym omówionym tu dziele, czyli Tryptyku Drezdeńskim. Trudno znaleźć w ikonografii bezpośrednią analogię, lecz hełmy z daszkiem występowały już wcześniej na terenie Italii, o czym świadczy choćby fresk Spinella Aretina, Bitwa morska między Wenecją a flotą Fryderyka Barbarossy ${ }^{46}$. Za pewną dalszą analogię może służyć również dużo późniejszy obraz Paola Uccella Ŝ́w. Jerzy i Smok z lat około 1458-1460 (Musée Jacquemart-André, Paryż), na którym konna postać świętego również nosi hełm z daszkiem. Bardzo interesujące przedstawienie zbrojnego możemy również odnaleźć na brązowych Wrotach Rajskich Lorenza Ghibertiego (ok. 1425-1452, Baptysterium San Giovanni, Florencja); w kwaterze Spotkanie Salomona i królowej Saby widać postać trzymającą rękę na rękojeści krótkiego korda, w hełmie o dzwonie muszlowatym oraz o naramiennikach podobnego kształtu. Hełm nie posiada daszku, lecz dzwon wygląda podobnie ${ }^{47}$. Na koniec opisu zbroi świętego warto zwrócić uwagę na kolor metalowych części. Zbroja nie wygląda na wykonaną ze zwykłej stali, której barwę ma część kolczej plecionki przy szyi i na wysokości ud. Istnieje kilka możliwości wytłumaczenia koloru metalowych płyt. Brąz mógł stanowić nawiązanie do tradycji antycznej. Emaliowanie lub złocenie zbroi oraz ukazanie skórzanych, emaliowanych (?) elementów mogło mieć nieco inne podłoże. Jako hipotezę można przyjąć nawiązanie do idei relikwii, gdyż to przy użyciu złota i emalii wykonywano większość ówczesnych relikwiarzy złotniczych. Wpisywałoby się to w szeroką prezentację drogocennych, świętych relikwii, jakie posiadała brugijska kolegiata, a obraz jest ich ostentacją - szczątków Krzyża Świętego, ramienia św. Jerzego, kapy św. Donacjana ${ }^{48}$. Wniosek dotyczy również postaci archanioła Michała z opisanego niżej Tryptyku Drezdeńskiego, którego

46 Dzieło zostało namalowane w Palazzo Publico w Sienie około 1400, David Nicolle, Italian Medieval Armies 1300-1500 (Oksford: Osprey Publishing, 1983), reprinted (2004), 27.

47 Paolo Uccello Św. Jerzy i Smok z lat koło 1458-1460 (Musée Jacquemart-André, Paryż), Wrota Rajskie Lorenza Ghibertiego (ok. 1425-1452, Baptysterium San Giovanni, Florencja); Sztuka Świata, t. 5 (Warszawa: Arkady, 2001), 121-123.

48 Ziemba, Sztuka Burgundii, t. 2, 666-667. 
zbroja i hełm nie mają kolorów stali, a być może były emaliowane, gdyż różnią się barwą od przedstawionych na tryptyku złotych (złoconych?) detali.

Podsumowując opis uzbrojenia zawartego w Madonnie kanonika Jorisa van der Paele, warto podkreślić pieczołowitą dbałość o oddanie detali uzbrojenia, zwłaszcza zbroi, która została uwieczniona z najdrobniejszymi szczegółami jej konstrukcji, takimi jak nity, sprzączki itp. Ujawnia się w tym gruntowna wiedza artysty o militariach, tak włoskich, jak i północnoeuropejskich. Istnieje wszakże i ta możliwość, że artysta połączył znane mu elementy uzbrojenia w całość niekoniecznie zgodną z rzeczywistością, czyniąc to dla wzmożenia siły przekazu i pokreślenia szczególnej roli św. Jerzego jako patrona fundatora i patrona rycerstwa, co podnosiłoby zarazem prestiż samego kanonika - zleceniodawcy dzieła.

\section{Tryptyk Drezdeński}

W Tryptyku Drezdeńskim, powstałym w 1437 r., centralna część ukazująca tronującą w kościele Marię z Dzieciątkiem dopowiedziana jest malowidłami umieszczonymi w dwóch bocznych skrzydłach. Po prawej stronie widnieje św. Katarzyna Aleksandryjska, natomiast po lewej - obok klęczącego donatora - stoi archanioł Michał. Postać donatora nie została zidentyfikowana, może nim być (sądząc po uszkodzonych herbach na ramie) ktoś z genueńskiej gałęzi rodziny Giustinianich lub lukkańskiej rodziny Burlamachi, albo też (ze względu na strój) jest to osobistość $\mathrm{z}$ dworu burgundzko-niderlandzkiego ${ }^{49}$. Nie daje to żadnych przesłanek dla określenia przedstawionych w tryptyku typów uzbrojenia. Stojący obok w zbroi archanioł Michał trzyma hełm przy lewym ramieniu, prawą ręką dzierży włócznię. Archanioł jest uzbrojony w miecz o dwuręcznej rękojeści i trudnej do rozpoznania głowicy. Ma na sobie pełną zbroję płytową, a także przewieszoną przez lewe ramię tarczę jeździecką. Napierśnik zbroi posiada w górnej części dwa dyski, służące do mocowania łańcuszków łączących głowicę miecza i zwyczajowo puginału. Była to praktyka $\mathrm{z}$ drugiej połowy XIV w., mająca zapobiegać zgubieniu broni ${ }^{50}$. Oprócz tego widoczne są trzy pasy, rozchodzące się symetrycznie ze środka, układające się w odwróconą literę V. Być może te wysadzane drogimi kamieniami listwy są tylko zdobieniami albo też napierśnik był zmontowany z kilku płyt. $U$ dołu napierśnika znajduje się szorca, złożona z sześciu rzędów nitowanych, prostokątnych płytek metalu. Zwisają spod niej dwa rzędy prostokątnych, skórzanych, zdobionych pasków, spod których wystaje dochodzący do połowy uda płat kolczugi. Pewną analogię dla zbroi archanioła stanowią kirysy wyobrażone na miniaturach wspominanej Wojny Trojańskiejpi ${ }^{51}$ Ilustracje

49 Ziemba, Sztuka Burgundii, t. 2, 193-195 (tam pełna literatura w przypisach).

50 Michał Bogacki, Broń wojsk polskich w okresie średniowiecza (Zakrzewo: Replika, 2009), 257.

${ }^{51}$ Historii Wojny Trojańskiej-folio 10v, 83r, 107r, 125r, http://dlib.gnm.de/item/Hs998/html, dostęp: 11 VI 2018. 
przedstawiają również napleczniki zbroi, namalowane w ten sam sposób. Na manuskrypcie Kriegstechnik, z Zentralbibliothek w Zurychu - można zobaczyć podobnie odzianego zbrojnego ${ }^{52}$. Badacze zwrócili już uwagę na takie kirysy i skonfrontowali ich wizerunki ze źródłami pisanymi. Taką zbroję białą określa się mianem „raka”, ze względu na podobieństwo układu folg do pancerza skorupiaka ${ }^{53}$. Źródła z terenu Prus Krzyżackich podają, że na początku XVI stulecia białe kirysy folgowe nazywano terminami Krebs lub Krebis ${ }^{54}$.

Możliwe jest jeszcze inne rozpoznanie wizerunków na omówionych powyżej miniaturach. Otóż teoretycznie wizerunki mogłyby przedstawiać płaty, czyli kirysy folgowe kryte. Lech Marek w swej publikacji na temat uzbrojenia z zamku Szczerba na Śląsku zaprezentował dwa dzieła z 1482 r., w których zbrojni noszą płaty o metalowych folgach ułożonych jak na obrazach van Eycka i omówionym powyżej malarstwie miniaturowym ${ }^{55}$. W tym przypadku widać główki nitów i inny kolor materiału, co sugeruje, że metalowe folgi są przykryte tkaniną. W przypadku omawianych dzieł van Eycka widać, iż jest to goły metal. Podobnie do wspomnianych wizerunków wygląda naplecznik zbroi św. Jerzego namalowany w Madonnie van der Paele, gdzie wyraźnie widać zachodzące dachówkowato metalowe folgi. Pewne podobieństwo zachodzi również w przypadku jednego ze zbrojnych zobrazowanych przez van Eycka na omówionym dalej, nowojorskim Ukrzyżowaniu.

Nogi archanioła są chronione przez pełne płytowe bejgwanty. Nabiodrki, czyli ochraniacze uda, są widoczne tylko częściowo. Nakolanek jest złożony z miski oraz dwóch dolnych i górnych folg, nagolenniki zaś oraz trzewiki są złożone $\mathrm{z}$ siedmiu metalowych części - folg. Ramiona zabezpieczone zostały przez muszlowate naramienniki, spod których wystają trzy rzędy pasków skórzanych. Płytowa opacha jest częściowo ukryta. Nałokietniki są duże, z trzema graniami, gotyckie w formie. Skrzydlaty kształt został podkreślony jeszcze przez lamówkę. Ostatnim elementem osłony rąk są płytowe zarękawia. Bardzo interesujący jest hełm. Jest to egzemplarz o dzwonie sferycznym muszlowato wystylizowanym i posiadającym z przodu daszek. W górnej szczytowej części jest grzebieniowate zdobienie, zakończone zwieńczeniem (krzyżem?). Natychmiast nasuwa się skojarzenie z omówionym wcześniej hełmem św. Jerzego namalowanym przez van Eycka w Madonnie van der Paele.

Archanioł trzyma w ręku włócznię zakończoną dużym, lancetowatym grotem z poprzeczką, należącym do typu VI w typologii Andrzeja Nadolskiego ${ }^{56}$. Być

${ }_{52}$ Kriegstechnik,sygn.Ms. Rh.hist 33 Z Zürich Zentralbibliothek, folio 81, http://www.e-codices. unifr.ch/en/zbz/Ms-Rh-hist0033b/81v/0/Sequence-1172, dostęp: 11 VI 2018.

${ }_{53}$ Tadeusz Grabarczyk, Jazda zaciężna Królestwa Polskiego w XV wieku (Łódź: [Blue Note], 2015), 105.

54 Grabarczyk, Jazda zaciężna, 105.

55 Marek, „Medieval Armour from Szczerba Castle”, Acta Militaria Mediaevalia 4 (2008): 116, fig. 30,12 .

${ }_{56}$ Nadolski, Studia nad uzbrojeniem polskim w X, XI, XII wieku (Łódź-Wrocław: Zakład im. Ossolińskich, 1954), 55. 
może kształt grotu odgrywa w tym przypadku pewną rolę symboliczną i wiąże się to z tzw. włócznią św. Maurycego, według tradycji Longobardów utożsamianą z włócznią Longinusa, którą przebito bok Chrystusa ${ }^{57}$. Włócznia Maurycego-Longinusa była symbolem władzy monarszej ${ }^{58}$. Do dziś zachowały się trzy utożsamiane z tą bronią groty świętych włóczni: Grot Rzeszy, Królestwa Węgier (domniemany, słabo poświadczony źródłowo) oraz Królestwa Polski ${ }^{59}$. Obecnie uznaje się wiedeński Grot Rzeszy za obiekt pochodzenia karolińskiego z drugiej połowy VIII w. Znany jest także grot z Wagharszapat w Armenii, o którym wspominają źródła trzynastowieczne jako o sacra lancea ${ }^{60}$. Analogiczne przykłady grotów zostały dalej podane przy omówieniu nowojorskiego dyptyku Ukrzyżowania.

Na prawej kwaterze poliptyku malarz przedstawił postać św. Katarzyny z długim, dwuręcznym mieczem w dłoni. O mieczu niewiele można powiedzieć, gdyż na malowidle nie jest widoczny w całości. Głowica wygląda tak niemal jakby była wykonana z kryształu. Typologicznie można go zaliczyć do typu T, a nawet bardziej do typu T4 - w systematyzacji Oakeshotta i Głoska ${ }^{61}$. Pewne podobieństwo wykazuje głowica miecza typu XVIa, pochodzącego ze Słowacji, określana jako typ T4 (obecnie w muzeum w Bratysławie ${ }^{62}$. Jego rękojeść jest długa, dwuręczna, natomiast jelec wygląda jakby był przykryty okładziną. Prosty, o końcówkach zwróconych na dół, typologicznie plasuje się najbliżej typu 8 . Widoczny fragment głowni posiada idące od trzpienia krótkie i wąskie zbrocze, wypełnione metalowymi guzami lub może drogimi kamieniami. Głownia jest dość szeroka i posiada grań.

Konkludując, należy podkreślić realistyczny, a zarazem symboliczny charakter ukazanego uzbrojenia zaczepnego (włócznia skrzydełkowa jako Włócznia Longinusa, Święta Włócznia Rzeszy). Uzbrojenie ochronne archanioła, tak jak w przypadku postaci archanioła Michała z Poliptyku Gandawskiego i św. Jerzego z Madonny van der Paele, zawiera elementy wyraźnie realistyczne - jak tarcza, kolczuga osłony rąk i nóg. Pewne wątpliwości natomiast może wzbudzać napierśnik z płytkową szorcą i paradny hełm. Łączenie miecza za pomocą łańcuchów przymocowanych do napierśnika w latach trzydziestych XV w. było już anachronizmem. Być może chodziło o świadomą archaizację albo też - czego nie można całkowicie wykluczyć - to okres kultywowania pewnych zwyczajów (w wielu krajach Europy był po prostu dłuższy). Niewykluczone, że artyści w czasach van Eycka „wytwarzali” paradne zestawy uzbrojenia, złożone z różnych elementów mających

57 Marek Dulinicz, „Lancea sacra - wędrówka idei i przedmiotów”, w Wędrówka rzeczy i idei w średniowieczu, red. S. Moździoch, Spotkania Bytomskie, t. 5 (Wrocław: IAE PAN, 2004), 61-84.

58 Ibidem, 65.

59 Ibidem, 61-81.

60 Marek, „Średniowieczne uzbrojenie w Europie łacińskiej jako Ars Emblematica”, Wratislavia Antiqua 22 (2017).

${ }_{61}$ Robert Ewart Oakeshott, Sword in the age of chivalry (Woodbridge: Boydell Press, 1997), $105-107$.

62 Głosek, Miecze, 140, nr katal. 38; tab. XXXIII, il. 5. 
podkreślić wyjątkowość postaci, jak w przypadku symbolicznych dla stanu rycerskiego (do którego wszak aspirowali także mieszczańsko-patrycjuszowscy zleceniodawcy obrazów) - figur św. Jerzego czy św. Michała Archanioła. Niektóre formy broni i zbroi mogły imaginacyjnie nawiązywać do tradycji rzymskiej lub nawet greckiej. Obecnie można jedynie stwierdzić, że formy przedstawione przez flamandzkiego mistrza w jego poliptyku z Gandawy, tablicy z Brugii oraz tryptyku z Drezna - znajdują analogie pośród mnogości innych wizerunków broni pochodzących z drugiej ćwierci XV stulecia.

\section{Ukrzyżowanie i Sąd Ostateczny}

Nowojorski dyptyk Ukrzyżowanie i Sąd Ostateczny prezentuję tu jako czwarte spośród przebadanych dzieł - ze względu na jego (omówioną na wstępie) niepewną chronologię oraz atrybucję. Roboczo przyjmuję tu autorstwo van Eycka, nie wykluczając powstania dzieła już w jego późnym warsztacie, około 1440 r. - jak to uznał Till-Holger Borchert ${ }^{63}$. Na lewym skrzydle Ukrzyżowania nowojorskiego obrazu występuje wiele różnych militariów. Broń drzewcowa jest reprezentowana w tym dziele przez różne typy włóczni oraz halabard. Włócznie mają groty o kształcie lancetowatym, w typologii oznaczone numerem V. Namalowane są tu również dwa groty włóczni ze skrzydełkami, czyli typu VI. Skrzydełka tego grotu mają zakończenia wywinięte ku górze. Wizerunki grotów ze skrzydełkami można znaleźć na wielu obrazach z tego okresu, a także późniejszych, aż do końca XV w. Jednym z przykładów jest Są Ostateczny Stephana Lochnera namalowany około 1435 r. ${ }^{64}$ Również Mistrz z Rostocku przedstawił grot z poprzeczką w swym Ołtarzu Trzech Króli, wykonanym około $1425 \mathrm{r}^{65}$ Grot o dużym liściu i poprzeczce można znaleźć w scence z aniołami w Poliptyku Sądu Ostatecznego Rogiera van der Weydena ${ }^{66}$. Analogie występują także na terenie Polski. Takim przykładem jest malowidło w Strzelnikach z 1418-28 oraz Tryptyk Ukrzyżowania Mistrza Ołtarza św. Barbary (Wilhelma von Oche?) z kościoła parafialnego w Gaci, z około $1450 \mathrm{r}^{67}$ Jako hipotezę roboczą można przyjąć możliwość, że być może przedział czasowy,

${ }_{63}$ Por. przypis 15.

64 Renate Krüger, Dawne Niemieckie malarstwo tablicowe (Warszawa: Arkady, 1974), 8; więcej informacji w pozycjach: Julien Chapuis, Stefan Lochner. Image Making in Fifteenth-Century Cologne (Turnhout: Brepols Publishers, 2004); Frank Günter Zehnder, Stefan Lochner, Meister zu Köln: Herkunft - Werke - Wirkung (Catalogue de l'exposition tenue au Wallraf-Richartz Museum de la ville de Cologne, 3 décembre 1993 - 27 février 1994) (Cologne: Locher, 1993).

65 Friedrich Adolf Martens, "Der Dreikönigsaltar der ehem. Johanniskirche zu Rostock”, Beiträge zur Geschichte der Stadt Rostock 18 (1933): 79-102.

66 Ziemba, Sztuka Burgundii, t. 2, 249-250, 292, literatura w przyp. 398-399.

67 Marek, Broń biała, 308, il. ryc. 135a-b; przykłady innych typów włóczni piętnastowiecznych z terenów śląskich: s. 96 oraz ilustracje: 304 ryc. 131-132 a-d, szydła ryc. 140-144. 
w którym groty typu VI były stosowane - był znacznie dłuższy. Przykładem jest duży niemiecki lub austriacki grot tego typu znajdujący się w kolekcji Metropolitan Museum of Art w Nowym Jorku, datowany na lata 1425-1450 ${ }^{68}$. Zabytek mierzy $44 \mathrm{~cm}$ długości i został uznany za broń myśliwską.

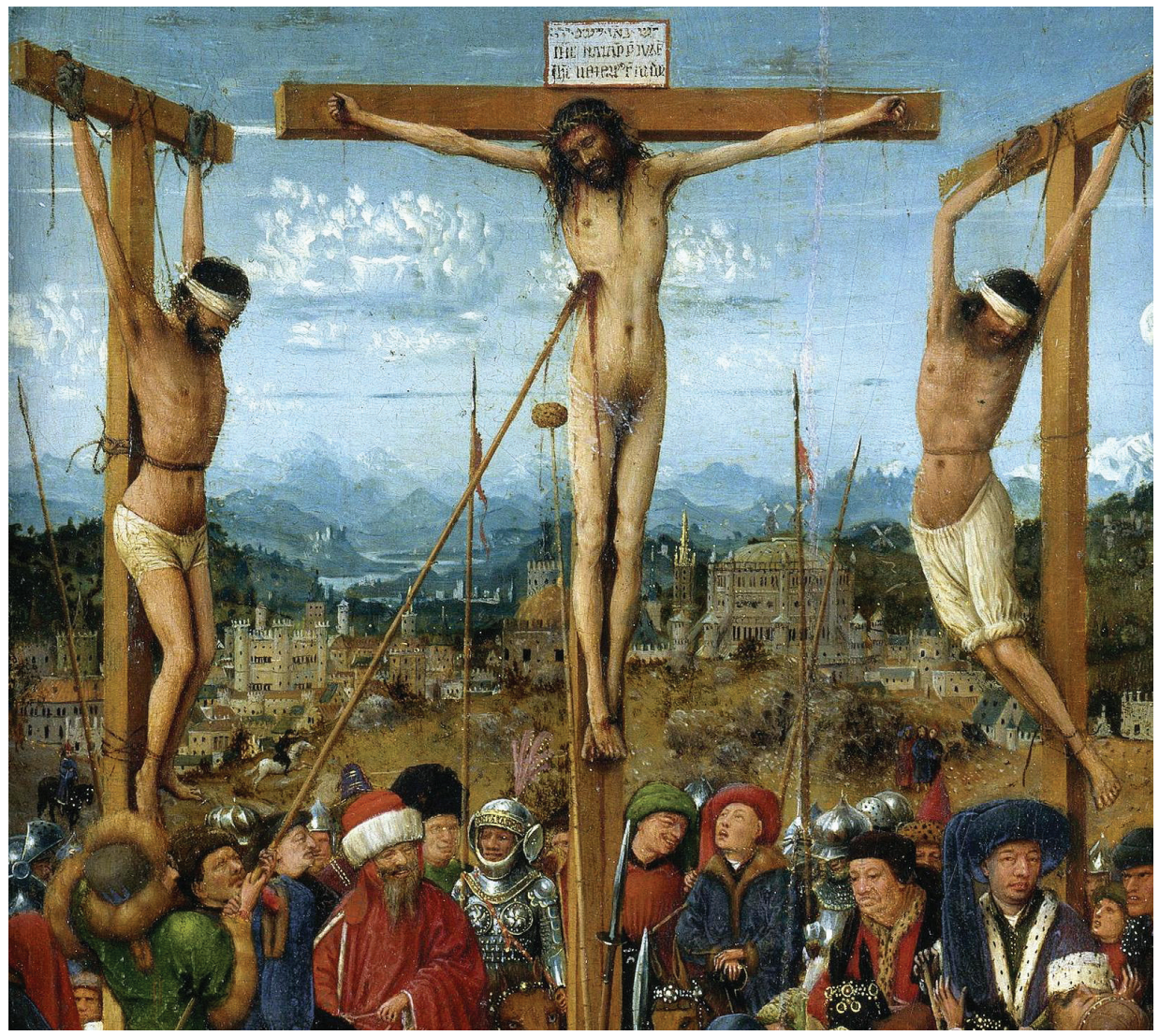

Fot. 5. Fragment dyptyku Ukrzyżowanie i Sąd Ostateczny, około 1440 (?), Metropolitan Museum of Art, Nowy Jork

Źródło: https://upload.wikimedia.org/wikipedia/commons/b/bd/Van_Eyck_-_The_Crucifixion\%3B_The_Last_ Judgment.jpg, dostęp: 11 VI 2018.

Tuż obok omawianej włóczni van Eyck (lub jego pomocnik) namalował jeszcze inny przykład broni drzewcowej, obiekt na pierwszy rzut oka przypomina broń nazywaną szydłem. Szydła pojawiły się w Europie w XIII w. i były wykorzystywane do XVI stulecia ${ }^{69}$. Broń ta posiada tuleję grotu $\mathrm{z}$ okrągłą, poziomą tarczką, a sam liść jest długi i bardzo wąski niczym kolec. W Ukrzyżowaniu widzimy jednak grot

\footnotetext{
${ }_{68}$ http://www.metmuseum.org/toah/works-of-art/14.25.321/, dostęp: 11 VI 2018.

69 Marek, Broń biała, 98-100.
} 
szerszy, lancetowaty - co oznacza, że broń należy zinterpretować jako nietypową włócznię. W scenie Sądu Ostatecznego zaś anioł unoszący się na lewo od Chrystusa prezentuje jako narzędzie Męki Pańskiej włócznię z grotem skrzydełkowym. Jest to zrozumiałe, gdyż chodzi o tę samą broń, co w scenie Ukrzyżowania, czyli włócznię Longinusa.

U dołu, po lewej stronie sceny Ukrzyżowania widnieje postać konnego, u którego zwisa przy prawym boku kord. Broń jest schowana w pochwie, posiada zapewne prostą, dość długą głownię, krótki jelec i długą, niemal dwuręczną, nożowatą rękojeść. Po prawej stronie stoją przedstawieni od tyłu dwaj piechurzy. Pierwszy od lewej nosi na głowie fantazyjny czerwony kapelusz, tułów ma okryty przeszywanicą, spod której wystaje kolczuga. Bardzo podobna ochrona ciała, wykonana z przeszywanej tkaniny, została pokazana na namalowanej przez van Eycka (lub przez jego warsztat) miniaturze Pojmanie Chrystusa $z$ Godzinek Turyńsko-Mediolańskich. Zbrojny trzyma w lewej ręce łuk azjatycki refleksyjny, ma przypięty kołczan ze strzałami, a przy lewym boku broń sieczną w pochwie. Łuk taki - wyglądający na azjatycki - można również znaleźć na jednej z miniatur wspominanego cyklu Wojny Trojańskiej Konrada $\mathrm{z}$ Würzburga ${ }^{70}$. Innym przykładem są miniatury Le Livre des merveilles $\mathrm{z}$ lat $1420-1440^{71}$. Głownia tej broni przy końcu wygina się szablowato. Jelec jest szeroki o końcówkach zagiętych do dołu. Rękojeść broni jest dość długa, widoczne na niej są nity do mocowania okładziny. Jelec wygląda na mieczowy. Trudno orzec, czy mamy do czynienia z wczesną szablą, kordem czy też tasakiem.

Podobną broń widać także przy drugiej postaci zbrojnego, tego w turbanie i z warkoczem do pasa. Sądząc po pochwie, głownia jednak musi być tu szersza od poprzedniej. Rękojeść tej broni, prawdopodobnie kordu, zawija się na końcu i jest zaopatrzona w metalowe kółko. Kordy i tasaki były uważane za broń plebejską, co nie oznacza, że przedstawiciele wyższych warstw jej nie stosowali, jak wskazuje dawny, ale szczególnie wyrazisty przypadek cesarza Ottona IV, walczącego tasakiem w bitwie pod Bouvines w $1214 \mathrm{r}^{72}$ Co interesujące, omawiana powyżej postać trzyma w ręku halabardę, różniącą się jednak od tej, jaką widać pod krzyżem, do którego przybito Chrystusa. Najstarszy przekaz dotyczący halabardy wymienia nazwy gesum oraz halbarte ${ }^{73}$. Chodzi tu o wspominaną już Wojne

70 http://dlib.gnm.de/item/Hs998/345/html, dostęp: 11 VI 2018.

71 Bibliothèque Nationale de France, Paryż, ms. Français 2810, fol. 72r). Kodeks zawierający francuskie tłumaczenia Jeana le Long ksiąg: Marco Polo, Le Livre des merveilles; Odoric de Pordenone, Itinerarium de mirabilibus orientalium Tartarorum; Guillaume de Boldensele, Liber de quibusdam ultramarinis partibus et praecipue de Terra sancta; Lettres adressées au pape et réponse de Benoît XII; De l'estat et du gouvernement du grant Kaan de Cathay, empereur des Tartares; Jean de Mandeville, Voyages; Héthoum Lambronac, Fleur des estoires de la terre d'Orient; Riccoldo da Monte di Croce, Liber peregrinationis. Zob. http://gallica.bnf.fr/ark:/12148/btv1b52000858n/f151.imagehttp://gallica.bnf. fr/ark:/12148/btv1b52000858n/f151.image, dostęp: 11 VI 2018.

72 Bogacki, Bron wojsk polskich, 139.

73 John Waldman, Hafted Weapons in Medieval and Renaissance Europe (Leiden-Boston: Brill, 2005), 17-21. 
Trojańską Konrada z Würzburga ${ }^{74}$. Wczesną odmianę halabardy prezentuje zabytek pochodzący z Alzacji, datowany na XIII w. ${ }^{75}$ Kolejne przykłady wczesnych okazów to pochodzące z terenów Szwajcarii z XIV w., nieco przypominające broń z Ukrzyżowania, w tym znalezisko z Rorbas koło Zurychu, a także z Cormondreche koło Schwyz ${ }^{76}$. Mistrz Pasji z Karlsruhe przedstawił około 1440 r. w tablicach Poliptyku Pasji cały arsenał rozmaitej broni drzewcowej, w tym włócznie skrzydełkowe, a także różne typy halabard podobne do namalowanych na nowojorskim dyptyku van Eycka ${ }^{77}$. W XV w. drzewce halabard dochodziły do 220-248 cm długości ${ }^{78}$. Halabarda namalowana pod krzyżem Chrystusa ma żeleźce prostokątne zakończone u góry ostrym klinem. W górnej części żeleźca, po prawej stronie odchodzi poziomo drugi klin-hak. Całość przypomina nieco halabardę typu Sempach ${ }^{79}$.

Uzbrojenie ochronne pokazane w tej części dyptyku jest bardzo interesujące i zróżnicowane, sprawiając wrażenie, jakby pochodziło z kilku epok. Przy lewej krawędzi sceny Ukrzyżowania widać fragment postaci noszącej na głowie przyłbicę grand basinet o zasłonie mocowanej na tarczowym zawiasie skroniowym, pokrytej siecią otworów, bez wizury. Podobny model hełmu widać fragmentarycznie w części środkowej tego skrzydła dyptyku, tuż za kapalinem o cebulastym dzwonie. Grand basinety powstały w wyniku zmodernizowania przyłbicy starego typu, polegającego na zastąpieniu czepca kolczego i dodaniu do dzwonu płytowego podbródka, a także przez wydłużenie tyłu hełmu. Zmiany te nastąpiły około $1400 \mathrm{r}^{80}$ Jednak w pełni ukształtowane grand basinety, z podbródkiem i głębokim nakarczkiem, weszły do użytku od około $1410 \mathrm{r} .^{81}$ Lata dwudzieste i trzydzieste XV w. to okres popularności tej odmiany, zwłaszcza na obszarze Francji, Anglii i południowych Niemiec, co znajduje potwierdzenie w ikonografii. Na terenie Italii także występowały różne odmiany grand basinetów, lecz miały bardzo poważną konkurencję w postaci innego hełmu zamkniętego, czyli przyłbic nowego typu - armet. Van Eyck przedstawił grand basinet, o zasłonie z wieloma szczelinami - wizurami, na miniaturze Godzinek Turyńsko-Mediolańskich, zatytułowanej Modlitwa na plaży. Perforowane zasłony przyłbic nie były rzadkością w tamtym okresie. Tego typu zasłonę możemy znaleźć również na Ołtarzu Pasji z opactwa Garamszentbenedek autorstwa Tomasza z Koloszwaru (Tamás Kolozsvári), z 1427 r. ${ }^{82}$

74 Marek, Broń biała, 108.

75 Ibidem, 324 ryc. $151 \mathrm{~b}$.

76 Ibidem, 324, ryc. $152 \mathrm{a}-\mathrm{b}$.

77 Lilli Fischel, Die Karlsruher Passion und ihr Meister (Karlsruhe: Verlag G.Braun, 1952).

78 Marek, Broń biała, 125.

79 Żygulski, Broń w dawnej Polsce, 118.

80 Ibidem, 101.

81 Tobias Capwell, Armour of the English Knight 1400-1450 (London: Thomas del Mar, 2015), 95, fig. 1.93 .

${ }_{82} \mathrm{http} / /$ www.keresztenymuzeum.hu/collections.php? mode=work\&wid=73\&page=0\&vt=, dostęp: 11 VI 2018. Por. Wilfried Franzen, Tomáš z Kološváru, Oltářní retábl z benediktinského 
Interesującą analogię stanowi berliński armet, datowany na $1440 \mathrm{r} .{ }^{83} \mathrm{Hełm}$ ma kształt dzwonu stylizowanego na niemiecki grand basinet (w opisie określany jako bicoque, odmiana grand basinetu bardziej przylegająca do głowy), jakich wiele można zobaczyć na miniaturach wspomnianej Wojny trojańskiej Konrada z Würzburga ${ }^{84}$. Zasłona tego zabytku jest podobna do przedstawionej przez van Eycka, nie posiada wizury, tylko gęstą siatkę otworów $w^{85}$. Kolejną podobną przyłbicę z perforowaną zasłoną można znaleźć we wspomnianym manuskrypcie Kriegstechnik z Zurychu ${ }^{86}$. Przyłbicę o zasłonie mocowanej za pomocą okrągłych tarczek można zobaczyć na jednej z wyrzeźbionych figur Kreuztragung Christi, datowanej dawniej

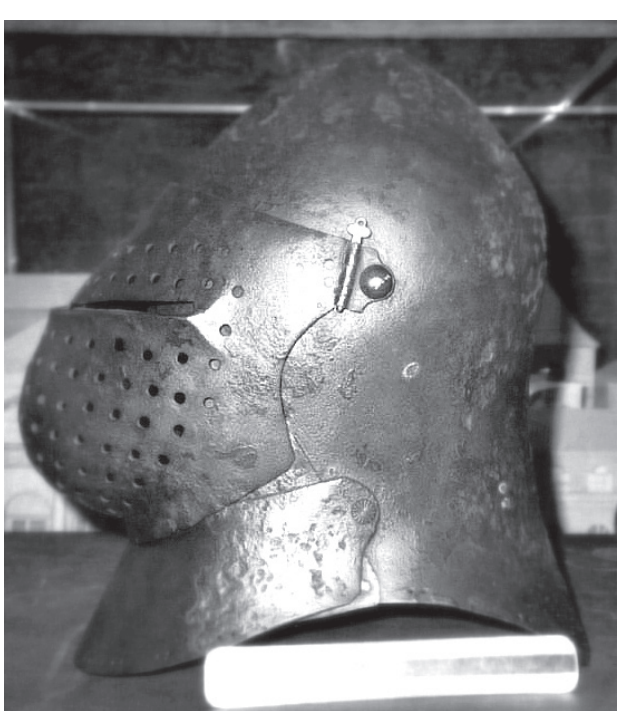

Fot. 6. Grand Basinet, około 1410-1430, francuski lub włoski, z nagrobku Jeana Salins de Vincellesa, Musee de Beaux-Arts Dijon, fot. ze zbiorów autora na lata $1415-1417^{87}$.

Obok zasłony grand basinetu przedstawionego tuż przy lewej krawędzi obrazu wystaje, ledwie widoczna, podniesiona zasłona przyłbicy psi pysk. Po prawej stronie pierwszego z krzyży widać częściowo hełm, być może kapalin z dzwonem zdobionym biegnącymi ukośnie graniami. Podobnie zdobiony dzwon ma kapalin z Oltarza Pokłonu Trzech Króli Stefana Lochnera ${ }^{88}$. Dzieło powstało w latach 1440-1445. Kapalin został namalowany w prawej części otwartego ołtarza, w kwaterze przedstawiającej św. Gedeona ${ }^{89}$. Dzwon tego kapalinu ma falujące granie i ostro zakończony szczyt. Pewne podobieństwo przejawia kapalin

opatstvísv. Benedikta v Hronském Beňadiku, w Karel IV, císař z Boží milosti, Kultura a umění za vlády Lucemburků 1310-1437, ed. Jiří Fajt (Praha: Academia, 2006), 583-584.

${ }_{83}$ Deutsches Historisches Museum Berlin, nr inw. W 1012, http://www.dhm.de/datenbank/ dhm.php?seite=5\&fld_0=AK204806, dostęp: 11 VI 2018 .

${ }_{84}$ Historia Wojny Trojańskiej, Hs998/70, dlib.gne.de/item/Hs998/html,aufnahme 428/206r,70/26v, dostęp: 11 VI 2018.

85 Scalini, The Armoury, 76, il. 10.

${ }_{86}$ Kriegstechnik, sygn. Ms. Rh. hist 33b folio 101v, http://www.e-codices.unifr.ch/en/zbz/Ms-Rh-hist0033b/101v/0/Sequence-1172, dostęp: 11 VI 2018.

${ }^{87}$ Lorch am Rhein, 1425, Skulpturensammlung (Inv. 8499), Bodemuseum Berlin, Geschichte, il. 128.

88 Caterina Limentani Virdis, Mari Pietrogiovanna, Arcydzieła malarstwa ołtarzowego (Warszawa: Arkady, 2004), 161.

89 Limentani-Virgis, Pitrogiovanna, Arcydzieła, 165 - wklejka, il. 51. 
o niewielkim rondzie, namalowany znacznie później na jednej z francuskich miniatur w egzemplarzu Wielkich Kronik Francji Jeana Froissarta ${ }^{90}$.

Przy krzyżu Chrystusa, po lewej stronie widnieje hełm o zaokrąglonym dzwonie, zdobionym pióropuszem, z płytowym podbródkiem i obojczykiem oraz tarczkami przyusznymi. Nad czołem hełm posiada mosiężne bądź złote zdobienia, charakterystyczne dla basinetów angielskich już od końca XIV stulecia, na przedstawianych pomnikach nagrobnych. Jako analogię można tu przytoczyć nagrobek sir Wiliama Phelipa, lorda Bardolf, zm. w 1441 r. znajdujący się w Dennington w Suffolk ${ }^{11}$. Również podobny motyw ma w części czołowej basinet sir Edmunda de Thorpe na pomniku nagrobnym w Ashwellthorpe w Norfolk, wykonanym około $1417 \mathrm{r}^{92}$ Niemal identyczny hełm, jak ten w scenie Ukrzyżowania, Jan van Eyck namalował w Pojmaniu Chrystusa z Godzinek Turyńsko-Mediolańskich - różnica polega na braku tarczek przyusznych. Równie interesująca jak hełm jest reszta uzbrojenia ochronnego tej postaci. Żołnierz ma na sobie biały napierśnik, złożony $\mathrm{z}$ nitowanych prostokątnych płytek-zbrojników, dachówkowato ułożonych - w sposób podobny, jak dolna część pancerza zbrojnego przy krzyżu łotra po prawej oraz jak pancerz archanioła Michała ze skrzydła z Sądem Ostatecznym. Pancerz ma na wysokości piersi dwa medaliony, sprawiając wrażenie typowej osłony tułowia z terenów Bałkanów lub Litwy, albo Rusi. Pewną analogię - acz daleką geograficznie i chronologicznie - mogłaby tu stanowić tzw. zbroja księcia Dowmonta z Pskowa z przełomu XIII i XIV w. ${ }^{93}$ Osłony rąk wojownika składają się z kolczugi, okrągłego naramiennika i trzech metalowych płytek oraz płytowego zarękawia. Całość uzbrojenia ochronnego sprawia wrażenie pewnej orientalizacji i wymieszania stylów Wschodu i Zachodu. Można by w tym widzieć wspomnianą wyżej strategię „bizantynizacji”, która łączyłaby wizerunek broni z ogólną postawą nawiązywania w obrazach religijnych do ich pradawnych, świętych, ikonowych prototypów i archetypów.

Po prawej stronie krzyża, z tyłu, znajdują się kolejne hełmy: przyłbica psi pysk, kapalin o cebulastym dzwonie i hełmy stożkowe. Kapalin o cebulastym dzwonie nasuwa skojarzenia z podobnym bojowym nakryciem głowy z terenu Polski (kapalin z Olsztynka), datowanym na przełom XIV i XV stulecia ${ }^{94}$. Należy również wspomnieć o bardzo zbliżonych kształtem kapalinach, przedstawionych we wspominanych już wielokrotnie miniaturach Godzinek

90 Bibliotèque Nationale de France, Paryż, ms. Français 2643, fol. 165v, http://gallica.bnf.fr/ ark:/12148/btv1b84386043/f354.item, dostęp: 11 VI 2018.

91 Capwell, Armour, 205, il. fig 2.14.

92 Ibidem, fig. 1.92.

93 Anatolij Nikolaevič Kirpičnikov, Voennoe delo na Rusi v XIII-XV vv. (Leningrad: Izdatel'stvo Nauka, Lenigradskoe otdelenie, 1976), 134, tab. 30.

94 Tadeusz Grabarczyk, Olgierd Ławrynowicz, Kapaliny w późnośredniowiecznej Polsce, 233; ryc. 1b, https://www.academia.edu/1863277/Kapaliny_w_p\%C3\%B3\%C5\%BAno\%C5\%9Bredniow iecznej_Polsce_Kettle-hats_in_late_medieval_Poland, dostęp: 11 VI 2017. 
Turyńsko-Mediolańskich, w Pojmaniu Chrystusa oraz Modlitwie na plaży $y^{95}$.

Psi pysk wyglądem przypomina nieco eksponat $\mathrm{z}$ Veste Coburg lub z Nowego Jorku ${ }^{96}$. Trzeba jednak przypomnieć, że okres popularności takich hełmów to lata siedemdziesiąte i osiemdziesiąte XIV stulecia. Oznacza to, że w latach trzydziestych XV w. był to typ już mocno przestarzały. Jednak w przypadku $D y p$ tyku Nowojorskiego nie do końca można stwierdzić, jakim sposobem zasłona hełmu została zamocowana, czy na zaczepie czołowym, czy na dwóch zawiasach skroniowych. Podobny zresztą hełm van Eyck umieścił na miniaturze Modlitwa na plaży w Godzinkach Turyńsko-Mediolańskich. Anachronizmy w stosowaniu przyłbic nie były wtedy wcale rzadkie; jako przykłady mogą posłużyć trzy niemieckie nagrobki z lat trzydziestych XV w.: Konrada von Brandscheita w dawnym kościele kolegiackim Sankt-Marien-Stiftskirche w Kyllburgu (1438); Eberharda Stoltza von Gaubickelheima w kościele parafialnym w Partenheim (1439) - oba na terenie Palatynatu Reńskiego; oraz Konrada Sinolta w kościele w Überau w Hesji (1439) ${ }^{97}$. Przedstawiono tam przyłbice z zasłonami klapowymi, mocowanymi na zawiasie czołowym. Do przykładów wizerunków tego typu przyłbic należy dodać jeszcze pieczęć wielkiego księcia litewskiego Witolda z 1418 r., na której także występuje przyłbica z zasłoną mocowaną na zawiasie czołowym.

Tablica Ukrzyżowania z Dyptyku Nowojor-

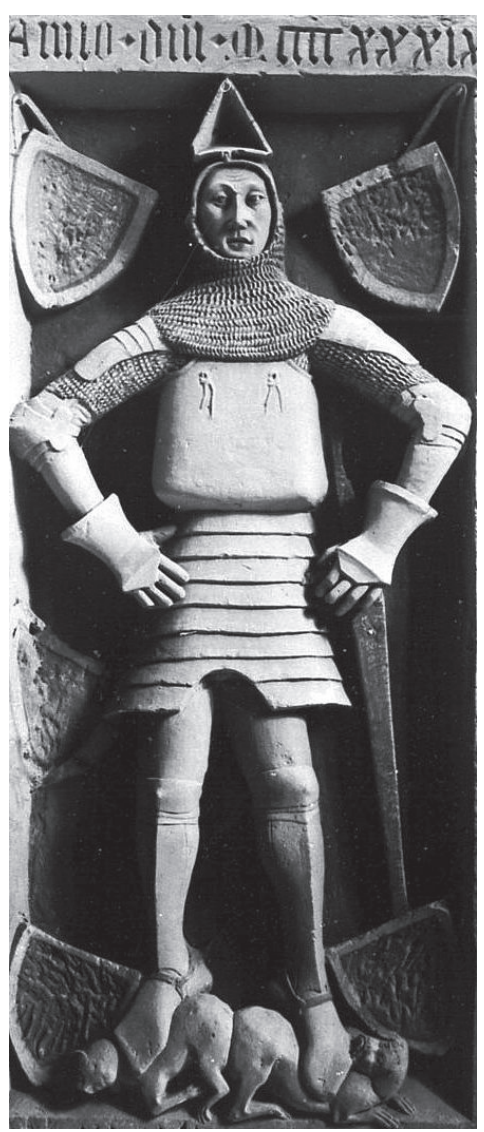

Fot. 7. Płyta nagrobna Eberharda Stoltza von Gaubickelheima w kościele parafialnym w Partenheim 1439

Źródło: http://previous.bildindex.de/bilder/ mi08596c06a.jpg, dostęp: 11 VI 2018. skiego pokazuje również inne osłony głowy. Jeden z wojowników, umieszczony pod prawym krzyżem z łotrem, ma na głowie hełm (?) sferyczny, wyglądający na wykonany ze skóry, tak jak i jego zbroja, której naplecznik przypomina konstrukcyjnie omówiony naplecznik zbroi św. Jerzego z Madonny van der Paele. Podobną analogię można znaleźć w powstałych około 1430-1435 r. w Utrechcie

95 Ziemba, Sztuka Burgundii, t. 2, 516, 518, il. 686, 688.

96 Scalini, The Armoury, 56, il. 24.

$97 \mathrm{http} / /$ effigiesandbrasses.com/search/?manuscript=4485\&page=16, dostęp: 11 VI 2017. 
Godzinkach Mistrza Zwedera van Culemborga, w miniaturze Pojmanie Chrystusa ${ }^{98}$. W postaci zbrojnego z nowojorskiego dyptyku van Eycka widać wyraźnie, że dolna część osłony tułowia została zbudowana z nitowanych płytek-zbrojników. Obraz pokazuje także naramienniki zbroi w postaci większej płytki i trzech folg. Ochrona tułowia wydaje się być omówionym wcześniej kirysem nazywanym „rakiem”. Na tej samej kwaterze dyptyku można również dostrzec hełmy stożkowe, ledwo widoczne w tłumie postaci. Postać umieszczona na prawo od widocznego hełmu z graniami, pośrodku między krzyżami Łotra a Chrystusa, ma hełm stożkowy z dodaną tarczką przyuszną. Być może dodatki w postaci takich osłon głowy miały służyć pewnej orientalizacji albo wręcz - podkreślanej wcześniej - archaizacyjnej „bizantynizacji” przedstawienia, gdyż trudno przypuszczać, aby takie odmiany były noszone na co dzień w Niderlandach lat trzydziestych XV stulecia.

W części dyptyku poświęconej Sądowi Ostatecznemu widać w górnej części obrazu, po prawicy Chrystusa, unoszącego się anioła. Trzyma on atrybut Męki Pańskiej (jeden z Arma Passionis) - włócznię Longinusa. Zakończona jest ona grotem o dużym, lancetowatym liściu i z poprzeczką. W typologii grotów Nadolskiego grot taki figuruje pod numerem $\mathrm{VI}^{99}$.

W tym skrzydle dyptyku najbardziej rzucającą się w oczy postacią, zgodnie z wymogami ówczesnej ikonografii Sądu Ostatecznego, jest archanioł Michał. W prawej ręce trzyma miecz o szerokiej klindze i dwuręcznej rękojeści, zakończonej głowicą w kształcie kwiatu. Kształt przypomina nieco typ Q w typologii Oakeshotta-Głoska ${ }^{100}$. W lewej ręce archanioł dzierży okrągłą tarczę, zdobioną drogocennymi kamieniami. Bardzo interesująca jest jego zbroja. Jako ochronę tułowia ma stosunkowo krótki, chroniący tylko tors, napierśnik płytowy z umieszczonymi na nim dwoma medalionami. Dół napierśnika jest przykryty wstęgą z niebieskiego materiału ze złotym napisem. Podobna wstęga znajduje się również na biodrach archanioła. Spod napierśnika wystaje pancerz płytkowy. Wygląda to tak, jakby konstrukcja płytowa została założona na konstrukcję zbrojnikową białą. Stosunkowo podobnie wygląda omówiona wcześniej zbroja św. Jerzego z Madonny van der Paele, gdzie kirys nałożono na konstrukcję z płytek.

Ochronę nóg stanowią miseczki nakolanka, podobne do przestawionych w Madonnie van der Paele, oraz osłony goleni. Osłony goleni wyglądają jakby wykonano je ze skóry bądź metalu obłożonego kolorową tkaniną. Podobne można dostrzec na wspomnianej miniaturze utrechckiego Mistrza Zwedera van Culemborga w Godzinkach z Walters Art Museum w Baltimore. Widoczne są tam wyraźnie listwy metalowe o złotym kolorze. Przypomina to szynowe konstrukcje

98 Pojmanie Chrystusa, Baltimore, Walters Art Museum, Ms. W. 168 folio 52v, http://www. thedigitalwalters.org/Data/WaltersManuscripts/html/W168/description.html, dostęp: 11 VI 2018.

99 Nadolski, Studia nad uzbrojeniem, 55.

100 Głosek, Miecze, 26, ryc. 3. 
czternastowieczne, kiedy to stosowano różne materiały organiczne łączone z metalem, by ostatecznie przejść do płytowych, rurowatych osłon, wykonywanych ze stali ${ }^{101}$.

\section{Podsumowanie}

W omówionych czterech dziełach Jana van Eycka (i/lub jego warsztatu), należy zwrócić uwagę na kilka istotnych aspektów. W kategorii uzbrojenia zaczepnego mamy do czynienia z różnymi rodzajami broni, które mieszczą się, wedle dzisiejszej wiedzy, w ówczesnych realiach. Przedstawiona tam broń drzewcowa, a więc włócznie i halabardy, była w powszechnym użyciu. Wyjątek może stanowić symboliczna włócznia Longinusa - nazywana Włócznią św. Maurycego, Świętą Lancą, Włócznią Rzeszy Świętej - o specyficznym grocie (typu VI), i chociaż nie można całkowicie wykluczyć, że był on ciągle w sporadycznym użyciu, to jednak jego ukazanie w licznych przedstawieniach obrazowych tego czasu, w tym u van Eycka, wynikało z konwencji ikonograficznej oraz z długiej tradycji kultu tej włóczni jako relikwii. Broń sieczna reprezentowana przez miecze i kordy również była w pierwszej połowie XV w. czymś oczywistym i stosowanym w militarnej praktyce. Łuk azjatycki, refleksyjny, nie był natomiast w tej części Europy powszechnym orężem bojowym. Na tereny Niderlandów mógł dostać się drogą handlową z Węgier, Rusi, Litwy lub Prus Krzyżackich. Łuki azjatyckie były jednak przedstawiane przez artystów w okresie późnego średniowiecza - na ogół tam, gdzie twórcy chcieli przedstawić orientalny charakter zbrojnych wojowników i żołnierzy, dla podkreślenia scenerii starożytnego Wschodu, w której wszak rozegrała się historia życia i Pasji Chrystusa.

Uzbrojenie ochronne przedstawione przez van Eycka to bardzo interesujący temat do analiz i rozważań. W szerokim spektrum odmian znajdujemy formy w pełni nowoczesne, jak przyłbice grand basinets, kapaliny o cebulastym dzwonie zakończonym sterczyną czy hełmy z daszkiem o paradnych kształtach - owszem, fantazyjnych, ale wcale niekoniecznie fantastycznych; ich realnego stosowania w ówczesnym uzbrojeniu paradnym nie można wykluczyć. Wśród odmian przestarzałych, przedstawionych głównie na nowojorskim dyptyku Ukrzyżowania i Sąu Ostatecznego, można zauważyć hełmy o stożkowatym dzwonie oraz przyłbicę psi pysk, przypominającą nieco okaz z Veste Coburg, o zasłonie mocowanej na zawiasie czołowym. Czy takie osłony głowy były jeszcze w użyciu na terenie Niderlandów w latach trzydziestych XV w. - trudno orzec. Wprawdzie okres popularności takich hełmów to lata siedemdziesiąte i osiemdziesiate XIV stulecia, niemniej odmiany uzbrojenia bywały w użyciu czasem i dłużej niż dziesiątki lat. Zbroje płytowe z Kastenbrustem i kirysem "rakiem” to kolejne realne i nowoczesne elementy uzbrojenia, uwiecznione przez van Eycka.

101 Jan Śliwiński, W poszukiwaniu zbroi doskonałej XIV w. (Poznań: Wydawnictwo Św. Jerzego, 2013), 62; 83, rys. 81. 
Następnym omówionym typem są białe pancerze płytkowe. Elementy płytkowe, np. szorce, a nawet trzewiki, występują w ikonografii w drugiej połowie XIV i w połowie XV w. dość licznie. Wskazują na to przykłady miniatur z Wojny trojańskiej Konrada z Würzburga czy szereg niemieckich nagrobków, m.in.: Johanna I von Wertheima (zm. 1407) w kościele w Wertheim, Badenia-Würtembergia ${ }^{102}$; Kunza Haberkorna (zm. 1421) z kościoła Joannitów w Würzburgu (ob. Bayerisches Nationalmuseum, Monachium) ${ }^{103}$; nieznanego rycerza w katedrze w Miśni (ok. 1430) ${ }^{104}$. Można przypuszczać, że elementy pancerzy płytkowych bądź łuskowych występowały w realiach późnego średniowiecza, chociaż rzadko, o czym świadczy brak znalezisk archeologicznych z pierwszej połowy XV w., które można by było połączyć z użyciem takich elementów zbroi na terenie Europy Zachodniej i Środkowej. Napierśniki płytkowe białe były w tym czasie w użyciu na terenie Litwy i Rusi ${ }^{105}$. Oznaczałoby to, że przedstawiając taki pancerz artysta dokonał świadomej orientalizacji bądź „bizantynizacji”.

Warto podkreślić bardzo duży realizm militariów zawartych w obrazach, jakkolwiek malarz niekiedy uciekał się do niespotykanego w rzeczywistości łączenia różnych elementów ochronnych, jak w przypadku wizerunków św. Jerzego $i$ archanioła Michała. Zabiegi tego typu miały być może na celu efekt niezwykłości, „nieziemskości”, a przez to - uwydatnienia „niebiańskości” archanioła, którego zbroja mogła być symbolem boskiej „sprawiedliwości i czystości”, a hełm „sądu niezawodnego", zgodnie z biblijną Księgą Mądrości (Biblia Tysiąclecia: 5,18) lub też - za Księgą Izajasza $(59,17)$ - sprawiedliwości i zbawienia. Święty Jerzy, jako patron stanu i etosu rycerskiego, został obdarowany przez artystę wspaniałą zbroją w kolorze złota i z dużą liczbą drogocennych kamieni. Pewne elementy stroju, które mogą symbolizować pochodzenie rzymskie czy bizantyjskie, miały również podkreślić „,starożytny” rodowód postaci. Nawiązania do form uzbrojenia wschodniego, bizantyjsko-bałkańskiego lub ruskiego, stanowiłyby rodzaj stylizacji i archaizacji, sugerujący, iż został przedstawiony obronny strój „starodawny”, prachrześcijański i panchrześcijański, który dobrze wpisywałby się w ówczesną tendencję do naśladowania italo-bizantyjskich obrazów-ikon, uobecniających sacrum - „świętych obrazów”, „cudownych wizerunków” sprowadzanych z Italii lub też powiązanych $\mathrm{z}$ występującym w Italii kultem pielgrzymkowym. Nie dysponujemy obecnie pewnymi, jasnymi i w pełni sprawdzonymi kryteriami odróżniania tego, co w rozmaitych elementach historyczno-dokumentalnych dawnych obrazów (np. zaprezentowana w nich broń) jest czystą rejestracją rzeczywistego wyglądu przedmiotów, od tego, co składa się na konwencję artystyczną, co jest umowne,

102 Charles Boutell, Monumental Brasses and Slabs: An Historical and Descriptive Notice of the Incised Monumental Memorials of the Middle Ages (1847), reprint (London: Bell, 1947).

103 Jakob Heinrich v. Hefner-Alteneck, Trachten des christlichen Mittelalters: Nach gleichzeitigen Kunstdenkmalen. Vierzehntes und fünfzehntes Jahrhundert, Bd. 2 (Frankfurt: Keller [a.u.], 1854).

104 http://effigiesandbrasses.com/5598/20029/, dostęp: 11 VI 2018.

105 Bohan, Vajskovaya sprava, 88-93. 
stylizowane na potrzeby ekspresji dzieła i co bywa fantastyczną lub fantazyjną kreacją. Niemniej, przedstawiona tu analiza bronioznawcza wybranych dzieł Jana van Eycka pozwala w znacznej mierze uważać te dzieła (przy wszystkich wymienionych wyżej zastrzeżeniach) za reprezentację realistyczną, więc i za źródło wiedzy o dawnej broni, funkcjonującej w orbicie dworu burgundzko-niderlandzkiego i samego van Eycka. To przekonanie i tę analizę wspomagają badania nad podobnymi elementami obrazów mistrza i jego następców. Wykazały one, że w przedstawianiu tkanin (brokatowych i innych materiałów ubioru, tapiserii, dywanów), epigraficznych tekstach greckich i łacińskich, wizerunkach roślin, artyści, zwłaszcza van Eyck, posługiwali się obserwacją rzeczywistości i konkretną wiedzą o realiach. Odtwarzali niebywale dokładnie fakturę, splot i zabarwienie tkanin, oddawali krój liter i poprawne znaczenie obcojęzycznych słów, stosowali wzorniki motywów roślinnych o wielkiej wierności botanicznej. Podobnie było, choć te zakresy nie zostały jeszcze wystarczająco przebadane, w wyobrażeniach sprzętów liturgicznych i okołoliturgicznych (przedmiotów złotniczych, rzeźb z kości, metalu, kamienia etc.), a także w wielu (choć nie wszystkich!) przedstawieniach architektury gotyckiej. Mogę więc żywić nadzieję, że i moja bronioznawcza analiza pożytecznie wpisze się w ten obszar materiałowych badań nad malarstwem van Eycka i innych mistrzów wczesnoniderlandzkich. Być może dalsze badania spowodują odkrycie nowinek w bardzo obszernym materiale ikonograficznym $\mathrm{z}$ tamtego okresu i dadzą asumpt do weryfikacji podanych tu ustaleń, w czym może pomóc również archeologia. Może to oznaczać w praktyce dalsze przesunięcie granicy pomiędzy realizmem a symbolizmem na korzyść tego pierwszego.

Michał Michalak

Armament in the paintings of Jan van Eyck. Analysis of Medieval Weaponry. Realism or symbolism?

\section{Summary}

The article analyses the armament shown in four pieces of art created by Jan van Eyck: Ghent altarpiece (1432), The Virgin and child with Canon van der Paele (1434-1436), The Dresden Triptych (1437) and The Crucifixion and Last Judgement Triptych (1435-1440).

Among compared material there are also two miniatures from the Turin - Milan Hours cycle painted by Master G, who is identified with van Eyck. In order to compare examined armament, author of the article additionally analyses panel paintings of such artists as Konrad Witz, Paolo Ucello, Stefan Lochner, Herman Hitz. The sources of many military examples were the miniature cycles included in manuscripts: Trojan Wars (1441) and Le livres de marveilles (1420-1440).

Furthermore author presents images showed in Italian frescos as well as knightly tombstones found in Germany and England. Examined material includes also original 
monuments from the discussed era. Militaries introduced by the Bruggian painter represent a wide spectrum of offensive and protective type of armament.

Pole weapon was presented in form of few types of spears and halberds: spears with lanceloate arrowheads, leaf-shaped lance arrowhead and symbolic winged spear, otherwise known as Longinus spear. As for the blade weapons, they include swords, cutlasses and ballock daggers. Unfortunately, due to the presentation reasons, there is only fragmentary information regarding blade weapons. They are either hidden in scabbards or only partially visible. Van Eyck's Crucifixion scene introduces also ranged weapon as the reflex bow.

Whereas among the protective armament can be noted modern types of helmets such as great bascinets and kettle hats with pig-faced bascinets. On the other hand, discussed Crucifixion shows some of the old fashioned pig-faced bascinets with visors attached by the forehead clinch. Also, barely seen in the painting, conical helmets are examples of earlier centuries. However, author of the article questions the realism of the hemispherical helmet with parotid shields and plate chin armour. The embellishment of the helmet, as well as its chin can be related to English great bascinets showed on numerous tombstones. Helmet of the Archangel Michael in the Ghent altarpiece and The Dresden Triptych, as well as the one worn by St. George, looks almost unrealistic. Further analysis of those pieces of armour reveals similarities to head protection shown in other works of art; it doesn't fully prove their usage in the discussed era, but it certainly makes it probable.

Jan van Eyck introduced in his works various torso covers like: aketon, mail armour, scale armour, breast plate - kastenbrust, leg and hand plate armour. Beside atypical shield bucklers held by Archangel Michael, other shield examples may be considered as completely realistic images of armour. Author's main conclusion is that great Flemish master van Eyck presented far reaching realism in his works along with wide knowledge of militaries both local and foreign ones. 